\title{
The impact of across-slope forest strips on hillslope
}

\section{subsurface hydrological dynamics}

Leo M. Peskett ${ }^{a, b *}$

Alan M. MacDonald ${ }^{b}$

Kate V. Heal ${ }^{\mathrm{a}}$

Jeffrey J. McDonnell ${ }^{c, d}$

Jon E. Chambers ${ }^{\mathrm{e}}$

Sebastian Uhlemann ${ }^{\mathrm{e}, 1}$

Kirsty A. Upton ${ }^{b}$

Andrew Z. Black ${ }^{\dagger}$

aUniversity of Edinburgh, School of GeoSciences, Crew Building, Alexander Crum Brown Road, Edinburgh EH9 3FF, United Kingdom leo.peskett@ed.ac.uk

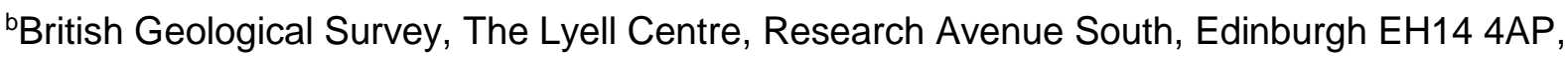
United Kingdom

'Global Institute for Water Security, School of Environment and Sustainability, University of Saskatchewan, Saskatoon SK S7N 3H5, Canada

${ }^{d}$ School of Geography, Earth and Environmental Sciences, University of Birmingham, Birmingham B15 2TT, United Kingdom

eBritish Geological Survey, Environmental Science Centre, Nicker Hill, Keyworth, Nottingham NG12 5GG, United Kingdom

\footnotetext{
1 Present address: Earth \& Environmental Sciences, Lawrence Berkeley National Laboratory, Berkeley, CA 94720, USA
} 
'Geography and Environmental Science, Tower Building, University of Dundee, Dundee DD1 4HN, United Kingdom

*Corresponding author: Leo Peskett, leo.peskett@ed.ac.uk

\section{Highlights}

- Soil moisture, groundwater and ERT data reveal moisture dynamics of a forest strip

- Sub-surface moisture dynamics altered within strip but not beyond $15 \mathrm{~m}$ downslope

- Water table depths within the forest are lower than the surrounding grassland

- Forest strip had no impact on groundwater connectivity during larger storms

\section{Keywords}

Electrical resistivity tomography (ERT); flooding; forest strip; groundwater; runoff; soil moisture

\section{Abstract}

Forest cover has a significant effect on hillslope hydrological processes through its influence on the water balance and flow paths. However, knowledge of how spatial patterns of forest plots control hillslope hydrological dynamics is still poor. The aim of this study was to examine the impact of an across-slope forest strip on sub-surface soil moisture and groundwater dynamics, to give insights into how the structure and orientation of forest cover influences hillslope hydrology. Soil moisture and groundwater dynamics were compared on two transects spanning the same elevation on a $9^{\circ}$ hillslope in a temperate UK upland catchment. One transect was located on improved grassland; the other was also on improved grassland but included a $14 \mathrm{~m}$ wide strip of 27-year-old mixed forest. Sub-surface moisture dynamics were investigated upslope, underneath and downslope of the forest over 2 years at seasonal and storm event 
timescales. Continuous data from point-based soil moisture sensors and piezometers installed at $0.15,0.6$ and $2.5 \mathrm{~m}$ depth were combined with seasonal ( bi-monthly) time-lapse electrical resistivity tomography (ERT) surveys. Significant differences were identified in sub-surface moisture dynamics underneath the forest strip over seasonal timescales: drying of the forest soils was greater, and extended deeper and for longer into the autumn compared to the adjacent grassland soils. Water table levels were also persistently lower in the forest and the forest soils responded less frequently to rainfall events. Downslope of the forest, soil moisture dynamics were similar to those in other grassland areas and no significant differences were observed beyond $15 \mathrm{~m}$ downslope, suggesting minimal impact of the forest at shallow depths downslope. Groundwater levels were lower downslope of the forest compared to other grassland areas, but during the wettest conditions there was evidence of upslope-downslope water table connectivity beneath the forest. The results indicate that forest strips in this environment provide only limited additional sub-surface storage of rainfall inputs in flood events after dry conditions in this temperate catchment setting. 


\section{Introduction}

There is renewed interest in forest strips (often termed "field boundary planting", "shelterbelts" or "buffer strips") as a flood management tool in wet upland environments (Dadson et al., 2017; Lane, 2017; Soulsby et al., 2017). Past work in the UK has shown that forest shelterbelts in improved grassland can control surface runoff (Wheater et al., 2008; Wheater and Evans, 2009). This work, and other studies, have reported significant increases in soil water storage capacity in shallow soils and increased infiltration rates within forest strips, and evidence of forest rain shadow effects on soil moisture in adjacent grassland (Jackson et al., 2008; Lunka and Patil, 2016; Marshall et al., 2009). Thus understanding the impacts of forest strips on subsurface hydrology appears key for controlling surface runoff and such interventions have the potential for "reducing run-off even when only present as a small proportion of the land cover" (Carroll et al., 2004, p. 357). If these findings can be generalised, there are obvious applications within a catchment management perspective for reducing flood risk. They are also important globally, given rapid changes in land use towards more mosaic landscapes and the effects this might have on hydrological processes (Haddad et al., 2015; Ziegler et al., 2004; Zimmermann et al., 2006).

While some evidence of forest strip impacts on hillslope hydrology exists, there has been limited mechanistic investigation of forest strip impacts on hillslope runoff processes. Of course, mechanistic studies on single completely forested hillslopes have been conducted for decades (Hewlett and Hibbert, 1967; Tromp-van Meerveld and McDonnell, 2006; Wenninger et al., 2004). But the 'black box' before and after treatments applied at the catchment scale (e.g. Hornbeck et al., 1970; Swank et al., 1988) have not been conducted at the hillslope scale. At best there are some hillslope intercomparisons (Bachmair and Weiler, 2012; Scherrer et al., 2007; Uchida et al., 2006, 2005) that explore hillslope response under different land covers. All 
of these approaches suffer from difficulties in controlling for significant heterogeneities even at the plot scale, a reliance on point-based data, and the challenges that these raise for developing transferable process understanding (Bachmair and Weiler, 2012).

Therefore, whilst plot scale studies have shown measurable impacts of forest cover on local hydrology, the use and application of these findings to assess the effectiveness of forest strip planting at the hillslope scale is limited. Specifically, forest strip planting raises important additional questions related to the location and structure of forest cover in landscapes and its interaction with other physical hillslope properties. For example, forest strips or vegetation patches in more arid environments appear to 'interrupt' hydraulic connectivity across landscapes (Fu et al., 2009; Liu et al., 2018) so may have variable effects on downslope hydrological processes. However, such questions have only been looked at in a few modelling studies (Reaney et al., 2014).

Here we examine the influence of a forest strip on hillslope sub-surface hydrological dynamics. We focus on a typical example of a narrow (14 m wide), mixed forest shelterbelt planted on improved grassland (land used for grazing that has been improved through management practices such as liming or drainage) - a configuration similar to that being used in some 'natural' flood risk management schemes in the UK (Environment Agency, 2018; Tweed Forum, 2019). We pair hillslope scale soil moisture and groundwater level measurements with timelapse electrical resistivity tomography (ERT) to help extrapolate from point-based measurements to hillslope scale process understanding. We build on work by Cassiani et al. (2012), Garcia-Montiel et al. (2008) and Jayawickreme et al. (2008), extending the ERT technique to investigate the interaction of two vegetation types and spatial orientation on the slope. Our specific questions are: 
1. How do across-slope forest strips alter soil moisture and groundwater level dynamics beneath the forest?

2. Do forest strips have downslope impacts on soil moisture and groundwater level dynamics?

We consider these questions over seasonal and storm event timescales, and also the potential implications from a flood risk management perspective.

\section{Methods}

\subsection{Site description}

The experiment was established on a hillslope in the $67 \mathrm{~km}^{2}$ Eddleston Water catchment, a tributary of the River Tweed in the Scottish Borders, UK (Figure 1). The catchment hosts an ongoing project initiated in 2010 to investigate the impact of natural flood management (NFM) measures aimed at controlling runoff from farmland and forest land (Werritty et al., 2010). The measures include tree-planting, establishment of holding ponds on farmland, re-meandering the Eddleston Water river, and the construction of 'leaky' dams in some sub-catchments (Tweed Forum, 2019).

Catchment characteristics are typical of much of the UK uplands. Topography is varied with elevations of $180-600 \mathrm{~m}$ and the climate is cool with mean annual precipitation of $1180 \mathrm{~mm}$ (at Eddleston village, 2011-2017), falling mainly as rainfall. Mean daily temperatures range from $3^{\circ} \mathrm{C}$ in winter to $13^{\circ} \mathrm{C}$. Daily evapotranspiration ranges from $0.2 \mathrm{~mm}$ in winter to $2.5 \mathrm{~mm}$ in summer (estimated using the Granger-Gray method (Granger and Gray, 1989) using data from the weather station in the catchment at Eddleston village). Bedrock throughout most of the catchment is comprised of Silurian impermeable well-cemented, poorly sorted sandstone greywackes (Auton, 2011). Extensive glaciation has affected the superficial geology and soil 
types. Soils on steeper hillsides are typically freely draining brown soils overlying silty glacial till, rock head or weathered head deposits. Towards the base of the hillslopes the ground is typically wetter and soils comprise sequences of gleyed clays and peats on sub-angular head deposits or alluvial deposits closer to the river. Land cover is mainly improved or semi-improved grassland on the lower slopes and rough heathland at higher elevations. Forest cover is typically mixed coniferous and deciduous woodland, concentrated along field boundaries.

The experimental hillslope is located $\sim 100-200 \mathrm{~m}$ from the Eddleston Water rising to $30 \mathrm{~m}$ above the river with a relatively uniform slope of $\sim 9^{\circ}$. Soil pit surveys $(0.7 \mathrm{~m}$ depth) found that soils comprise typically $0.15-0.20 \mathrm{~m}$ deep silty cambisols containing numerous sub-angular cobbles up to $60 \mathrm{~mm}$ length. Large roots $(<30 \mathrm{~mm})$ were prevalent in the top $0.20 \mathrm{~m}$ of the forest soils, with occasional large tree roots and frequent smaller tree roots $(<5 \mathrm{~mm})$ present down to the bottom of the soil pits. By contrast, small roots were prevalent in the top $0.20 \mathrm{~m}$ of the grassland soils, with no roots identified at the base of the soil pits (Figure S1). Borehole logs (Figure S1) and a grid of initial ERT surveys showed a clear layered structure to the underlying geology, with soils above a layer of silt/loam glacial till containing numerous large cobbles, which transition at 1.5-2 m depth into sub-angular head deposits or weathered rock head.

Soils on the hillslope are generally freely draining, although surface runoff was observed at the wettest times of year in the area upslope of the forest strip. Hydraulic conductivity of soils overlying head deposits has been measured as part of the wider project on a similar hillslope 2 $\mathrm{km}$ to the north which found median values of $21-39 \mathrm{~mm} \mathrm{~h}^{-1}\left(0.50-0.94 \mathrm{~m} \mathrm{~d}^{-1}\right)$ for improved grassland and $42 \mathrm{~mm} \mathrm{~h}^{-1}\left(1 \mathrm{~m} \mathrm{~d}^{-1}\right)$ for an $\sim 50$ year old plantation forest, and 119-174 $\mathrm{mm} \mathrm{h}^{-1}$ (2.86-4.18 $\left.\mathrm{m} \mathrm{d}^{-1}\right)$ for broadleaf forests $>180$ years old (Archer et al., 2013). The hydraulic conductivity of the glacial till was estimated to range from $<0.001$ to $1 \mathrm{~m} \mathrm{~d}^{-1}$ based on data from other locations in Scotland (MacDonald et al., 2012). Hydraulic conductivities of the underlying 
head deposits could not be measured directly using falling head tests in the piezometers as values were beyond the design limit of the test methodology $\left(40 \mathrm{~m} \mathrm{~d}^{-1}\right)$. However, elsewhere in the Eddleston catchment, the permeability of the head deposits has been measured as $500 \mathrm{~m}$ $\mathrm{d}^{-1}$ (Ó Dochartaigh et al., 2018). Hydraulic conductivity of the bedrock was not measured, but Silurian greywacke aquifers elsewhere in southern Scotland have been shown to have low productivity (Ó Dochartaigh et al., 2015), with an estimated average transmissivity of $20 \mathrm{~m}^{2} \mathrm{~d}^{-1}$ (Graham et al., 2009).

Particle size and organic matter content were determined from soil samples taken at $0.15 \mathrm{~m}$ and $0.6 \mathrm{~m}$ depth at all 14 soil moisture monitoring sites (Table S1). Particle size analysis used the sieving method for the proportion above $2 \mathrm{~mm}$ and a Beckmann Coulter LS230 particle size analyser for the proportion below $2 \mathrm{~mm}$, according to international standards (ASTM International, 2004). The soil texture is predominately silty loam with a substantial proportion of gravel and cobbles (22-58\% by mass). There is little variation between locations and transects, although the $0.6 \mathrm{~m}$ depth sample at the top of the grassland transect and one of the $0.15 \mathrm{~m}$ depth samples in the forest strip had slightly higher sand content than the other locations. Organic content was measured for the same samples using the loss on ignition method at $375^{\circ} \mathrm{C}$ for 24 hours (Ball, 1964), and was $2-7 \%$.

\subsection{Experimental setup}

The experiment consisted of two $64 \mathrm{~m}$ instrumented transects established at the same topographic elevation (212-195 m) on the hillslope and separated by $30 \mathrm{~m}$ (Figure 1). One transect was on improved grassland, whilst the other intersected, and was centred on, a $14 \mathrm{~m}$ wide strip of 27 year old fenced mixed forest containing Sitka spruce (Picea sitchensis), European larch (Larix decidua), ash (Fraxinus excelsior), hawthorn (Crataegus monogyna), oak 
(Quercus robur) and elder (Sambucus nigra). Tree height ranged from 7 to $14 \mathrm{~m}$ and rooting depths were estimated as 0-1.5 $\mathrm{m}$ for Sitka spruce and 0-2.5 $\mathrm{m}$ for the deciduous trees, based on trees of similar age on similar soils (Crow, 2005; Fraser and Gardiner, 1967). Both land cover types are typical of the wider catchment and much of the UK uplands, with the grassland used throughout the year for grazing sheep and occasionally horses.

Fourteen soil moisture sensors (Delta-T SMT150 with GP4 loggers) were installed in pairs at $0.15 \mathrm{~m}$ and $0.6 \mathrm{~m}$ depth at upslope, midslope and downslope elevations in each transect (3 pairs on the grassland and 4 pairs on the forest transect). Nine $50 \mathrm{~mm}$-diameter piezometers were installed at $2.5 \mathrm{~m}$ depth using a hand held rock drill at similar locations to the soil moisture sensors ( 3 on the grassland and 6 on the forest transect). The additional piezometers on the forest transect were installed close to the upslope and downslope boundaries of the forest. All piezometers were sealed with bentonite to $0.6 \mathrm{~m}$ depth and contained a $0.35 \mathrm{~m}$ screen at their base. All piezometers were instrumented with non-vented Rugged TROLL 100 loggers logging at 15-minute intervals and levels were checked manually every 3 months. A barometric logger (Rugged BaroTROLL 100) at the site was used to correct for atmospheric pressure. Two tipping bucket rain gauges were installed $16 \mathrm{~m}$ upslope and downslope of the forest to check for the influence of the prevailing wind on rainfall on either side of the forest (Figure 1).

Figure 1: a) Site layout and location in Scotland. Soil moisture sensors at $15 \mathrm{~cm}$ and 60 cm depth are marked '_15' and '_60' respectively and prefixed with 'F' and 'G' for the forest and grassland transects. 'BH_F' and 'BH_G' are piezometers on the forest and grassland transects respectively. TDR SM sensor: Time domain reflectometry soil moisture sensor; TBR: Tipping bucket rain gauge. Grey lines are contours in masl. Grey outline in the forest indicates the extent of the surveyed canopy. Dotted boundary of forest marks the location of the fence (which continues under the mapped canopy). b) 
Schematic cross sections of the forest and grassland hillslope transects, showing vegetation type, geology and locations of different sensors.
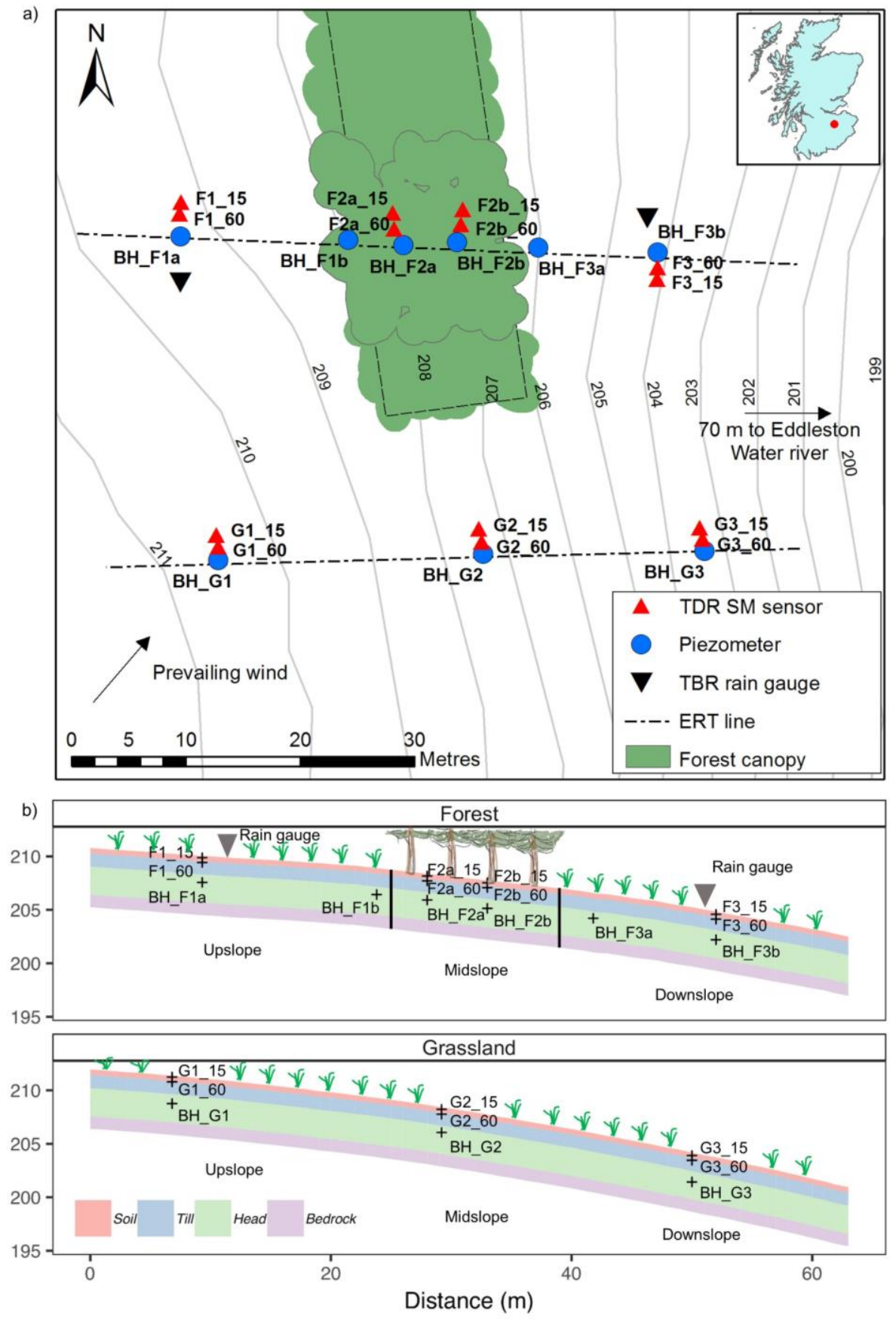

Peskett et al. 2020 Journal of Hydrology https://doi.org/10.1016/j.jhydrol.2019.124427 
The logging period was November 2016 to November 2018 inclusive. One of the soil moisture and rainfall loggers failed on the forest transect, resulting in a $\sim 5$-month data gap for the shallow soil moisture sensor at the top of the transect (F1_15), a 3-month gap in the upslope rain gauge, and a $\sim 1$-month gap in data for the other three sensors attached to this logger. The groundwater data was also discontinuous due to large seasonal variations in groundwater level leading to water table levels below the level of the sensors. The gaps in data have been taken into account in the analysis where necessary. Additionally, one of the upper soil moisture sensors in the forest (F2b_15) did not respond for any event, perhaps because it was in an air pocket, and was removed from the analysis. Two piezometers (BH_F2b, BH_F3b) which did not respond during the study period were also removed from the analysis.

Two soil temperature probes (Delta-T ST4) were installed at $0.15 \mathrm{~m}$ and $0.6 \mathrm{~m}$ depth at the top of the grassland transect, and temperature data were also collected from the pressure transducers at $2.5 \mathrm{~m}$ depth. Air temperature, wind speed and direction, solar radiation and rainfall data were obtained from an automated weather station $3 \mathrm{~km}$ north of the site at Eddleston village and a similar elevation of 200 masl. These datasets were used to estimate evapotranspiration and to infill missing rainfall data as explained in section 2.3.2. Most of the trees closest to the transect in the forest are conifers, but the deciduous trees had no leaves between mid-November and mid-April.

Initial 2D ERT surveys consisting of 6 lines at $2 \mathrm{~m}$ spacing were carried out in August 2016 across and down the slope to help characterise the geological structure of the site. A series of ten repeated 2D ERT surveys were then conducted between November 2016 and April 2018 along the forest and grassland transects. The surveys were undertaken using an AGI SuperSting R8 imaging system connected to arrays of 64 stainless steel pin electrodes positioned at $1 \mathrm{~m}$ intervals. Measurements were made using the dipole-dipole configuration with 
dipole sizes (a), of 1, 2, 3 and $4 \mathrm{~m}$ and unit dipole separations (n) of 1-8a. Time-lapse inversion of the data was performed using RES2DINV (Loke et al., 2013), which employs a regularised least-squares optimisation approach, in which the forward problem was solved using the finiteelement method.

\subsection{Soil moisture and groundwater data analysis}

The soil moisture and groundwater data were analysed using the whole time series to understand annual changes and through the selection of specific events to understand event dynamics. The whole time series data and event data were also examined on a seasonal basis, with the following definitions: Winter ('Wi': Dec-Feb), Spring ('Sp': Mar-May), Summer ('Su': Jun-Aug) and Autumn ('Au': Sep-Nov), These periods were defined based on the soil moisture data that showed full wetting up did not occur until late Nov-early Dec, providing a better baseline for comparison.

\subsubsection{Whole time series analysis}

Soil moisture and groundwater level data were first analysed for the whole time series to give an indication of seasonal patterns, discontinuities in the groundwater data and logger errors. Summary statistics included median values; minimum and maximum values; interquartile range; and graphical inspection of wetting up and recession characteristics. Given the discontinuity of the groundwater data, only the proportion of the year for which a water table was recorded and the range in levels were of interest, along with more descriptive details (e.g. recession behaviour) of the water table response to rainfall events. 


\subsubsection{Event analysis}

Soil moisture and groundwater events were selected for analysis by first identifying rainfall events and then finding the associated event in the soil moisture/groundwater time series. The rainfall events were selected automatically from the upslope rain gauge time series based on a total event rainfall of $\geq 8 \mathrm{~mm}$ and an intensity criterion that an event contained no period longer than 2 hours without rainfall. This resulted in 56 events, which was reduced to 52 events as described in the following paragraph. Characteristics were calculated for each event in the final event dataset, including total rainfall (TR, ranging from 8.2 to $52.6 \mathrm{~mm}$ ), mean hourly intensity (I, ranging from 0.5 to $2.5 \mathrm{~mm} \mathrm{~h}^{-1}$ ), a 5-day weighted antecedent wetness index (AWI, ranging from 1.3 to $48.3 \mathrm{~mm}$ ) (Kohler and Linsley, 1951) and the 28-day antecedent rainfall (AP28d, ranging from 13.2 to $138 \mathrm{~mm}$ ). The gap in the upslope rainfall gauge time series from 01/09/2017 - 02/12/2017 was filled directly with data from the weather station at Eddleston village, which was considered appropriate based on the small differences in rainfall recorded across multiple sites in the catchment. A full summary of the selected events is given in Table S2.

Events in the time series for the operational 13 soil moisture sensors were initially selected automatically by locating the point after the start of event rainfall where the 1-hour rolling mean smoothed soil moisture exceeded a gradient threshold of $>0.001 \mathrm{~m}^{3} \mathrm{~m}^{-3} \mathrm{~h}^{-1}$ and where the total change in soil moisture was $>0.012 \mathrm{~m}^{3} \mathrm{~m}^{-3} \mathrm{~h}^{-1}$. Events in the time series for the seven operational groundwater sensors were selected in the same way but with a gradient threshold of $>0.008 \mathrm{~m} \mathrm{~h}^{-1}$ and where the total change in groundwater level was $>0.001 \mathrm{~m} \mathrm{~h}^{-1}$ in the 1-hour smoothed groundwater data. These thresholds were determined iteratively by graphical inspection of several randomly selected events from each sensor. Saturation behaviour was identified in some of the soil moisture time series as a rapid rise in soil moisture to near saturation, followed by a plateauing in soil moisture and then a rapid decrease in value, which 
was captured in the algorithm using a combination of the gradient of the rising limb and the maintenance of a peak within $95 \%$ of the peak level for more than $1.5 \mathrm{~h}$.

Given the variety in types of response, all selected events were inspected manually. Four events were removed completely due to excessive noise, even in the smoothed soil water and groundwater time series, leading to spurious event characteristics across all locations. Further manual adjustments were made for particular locations in some events to adjust start and peak selection due to excessive noise and to correct peaks where very close consecutive events resulted in peak selection associated with the subsequent event. The final event dataset consisted of 52 events (Table S2).

The following metrics were calculated for each event, including: whether response occurred in the soil moisture or groundwater data $(\mathrm{R})$; time to response from the start of rainfall (TTR); time to peak from start of rainfall (TTPR); and maximum absolute rise (MR). Response was defined by the criteria above including, in the case of the piezometers, those that rose from an initially dry state.

Comparison of R, TTR, TTPR and MR between grassland and forest transects was made for a subset of nine events at the wettest points in the time series when the piezometer downslope of the forest responded (and most other sensors were also responding), to enable comparison of sensors with a more balanced design. Pairwise comparisons between sensors in the same domains (upslope, midslope and downslope) and depths on the different transects were also made for all responding sensors in the pair to enable analysis under a wider range of conditions. Tests for normality (Shapiro-Wilk) and homoscedasticity (Fligner-Killeen) were conducted prior to statistical testing. These showed that with a $\log _{10}$ transformation the majority of sensor datasets followed a normal distribution and all of them were homoscedastic. Given 
some deviation from normality but relatively uniform differences in variance, the non-parametric Kruskal-Wallis test was used to compare medians and Dunn's post-hoc test to determine where any significant differences occurred.

Logistic regression was used to test the relationship between event characteristics and whether sensors responded given the binary nature of the data. Spearman's rank correlation was used to assess associations between event characteristics and TTR, TTPR and MR. Prior to the exploration of the relationship between event characteristics and response metrics, co-linearity between the different event characteristics was checked (Table S3). There was some colinearity between event rainfall and event intensity, and also AWI and AP28d, which was considered in the interpretation of the results. All statistical analyses were conducted in $\mathrm{R}$ version 3.5.1 with significance defined as $p<0.05$.

\subsection{ERT data analysis}

The ERT surveys were carried out following variable antecedent rainfall conditions (Figure 2). After correction of the ERT model for effects of soil temperature using data from the nested temperature probes (at $0.15 \mathrm{~m}$ and $0.6 \mathrm{~m}$ depth) and the BH_G1 pressure transducer at $2.5 \mathrm{~m}$ depth, temporal changes in resistivity between the surveys were assumed to be due to changes in soil moisture content, based on relationships established in other studies (Brunet et al., 2010; Cassiani et al., 2009; Chambers et al., 2014). To factor out potential differences between material properties, comparisons in each of the transects were made relative to the May 2017 survey as it was the driest survey with the highest resistivities.

Resistivity contrasts between depths and locations on the different transects were analysed by averaging resistivities across different lateral or vertical groups of cells in the ERT datasets from 
each of the transects. Given some deviation from normality in resistivity distributions within groups, median resistivities were compared using the same non-parametric tests as for the insitu sensor data and a bias-corrected bootstrapping procedure used to estimate confidence intervals for each group.

Figure 2: Antecedent rainfall conditions for the ten ERT surveys. API: 5 day weighted antecedent rainfall (as described in text); AP24, AP7d and AP28d are total antecedent rainfall over 24 hours, 7 days and 28 days prior to the survey.

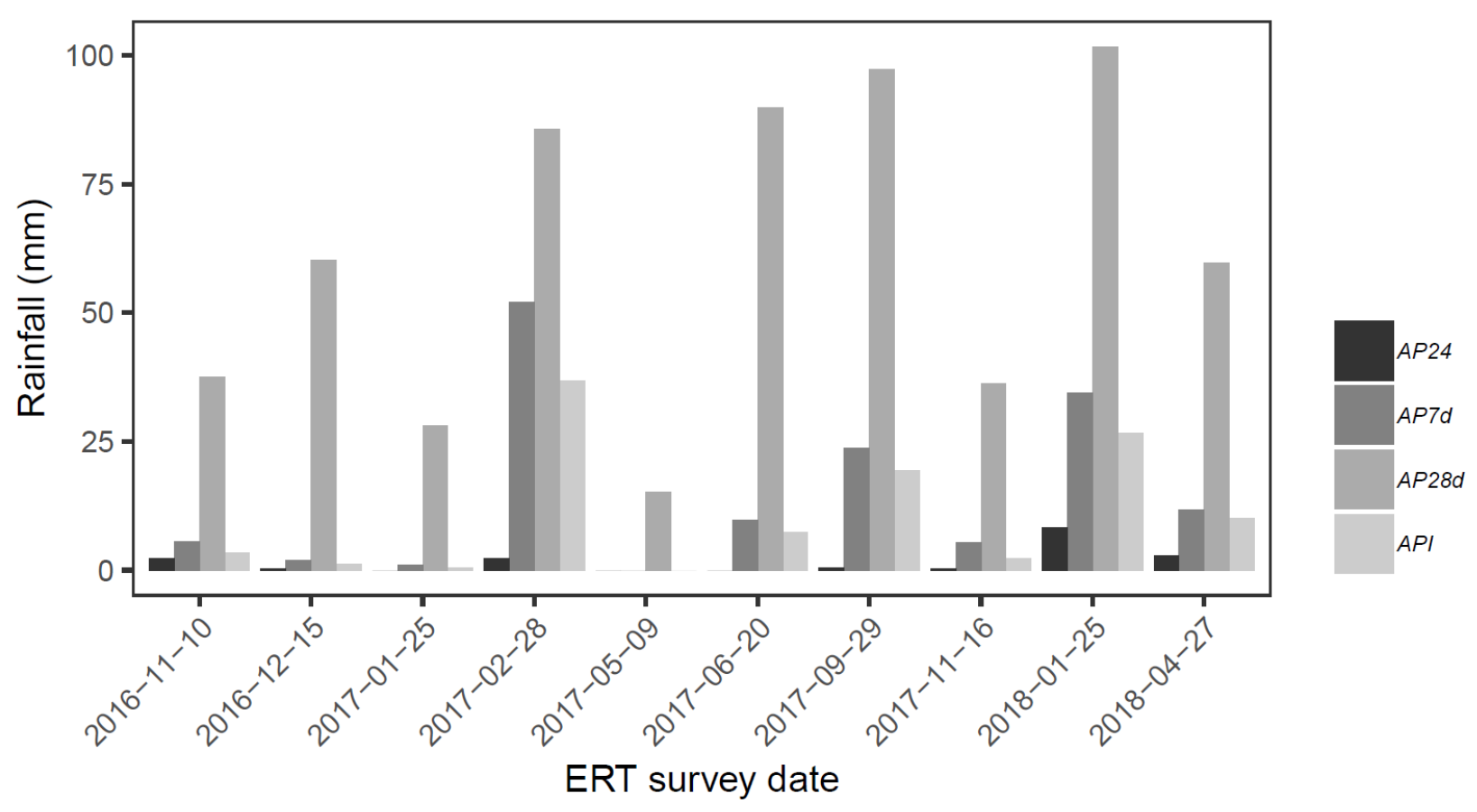




\section{Results}

\subsection{Seasonal sub-surface hydrological dynamics}

\subsubsection{Soil moisture content and groundwater level}

Soil moisture content had a distinct seasonal pattern, with generally drier conditions in summer and wetter in winter. This was most pronounced in the shallow soil moisture sensors and lasted longer in the forest compared to the grassland (April to December and April to July, respectively) (Figure 3). Saturation occurred during winter in most of the soil moisture time series on grassland areas as distinct plateaued peaks that also recessed rapidly (Figure 3). In most instances this was due to infiltration, but occasionally at locations F1_60 and G2_60 the water table rose above the level of the soil moisture sensor. Saturated soil moisture conditions were not apparent in the forested areas (F2 sensors).

Soil moisture content in the grassland areas upslope and downslope of the forest strip (F1 and F3 sensors) displayed similar behaviour to those on the grassland transect, with the exception of the $0.6 \mathrm{~m}$ depth sensor upslope (F1_60), which had a higher soil moisture content throughout almost the entire time series than the paired grassland sensor (G1_60), possibly due to the location in a shallow topographic depression. The upslope rain gauge had higher daily rainfall than the downslope gauge during the study period (paired t-test, $p<0.01$ ), probably due to the prevailing wind direction, but the mean difference was only $0.1 \mathrm{~mm} \mathrm{~d}^{-1}$.

Figure 3: Time series of a) 15-minute soil moisture (SM) and b) 15-minute groundwater level (GWL) data from the grassland and forest strip transects for the entire study period November 2016-November 2018. Soil moisture sensor F2b_15 was poorly responsive and possibly in an air pocket so data are not shown. Note different y-axis scales for GWL 
data. $c)$ Hourly rainfall data $(R)$ from the upslope rain gauge (aggregated from 15-minute data for clarity).

a)

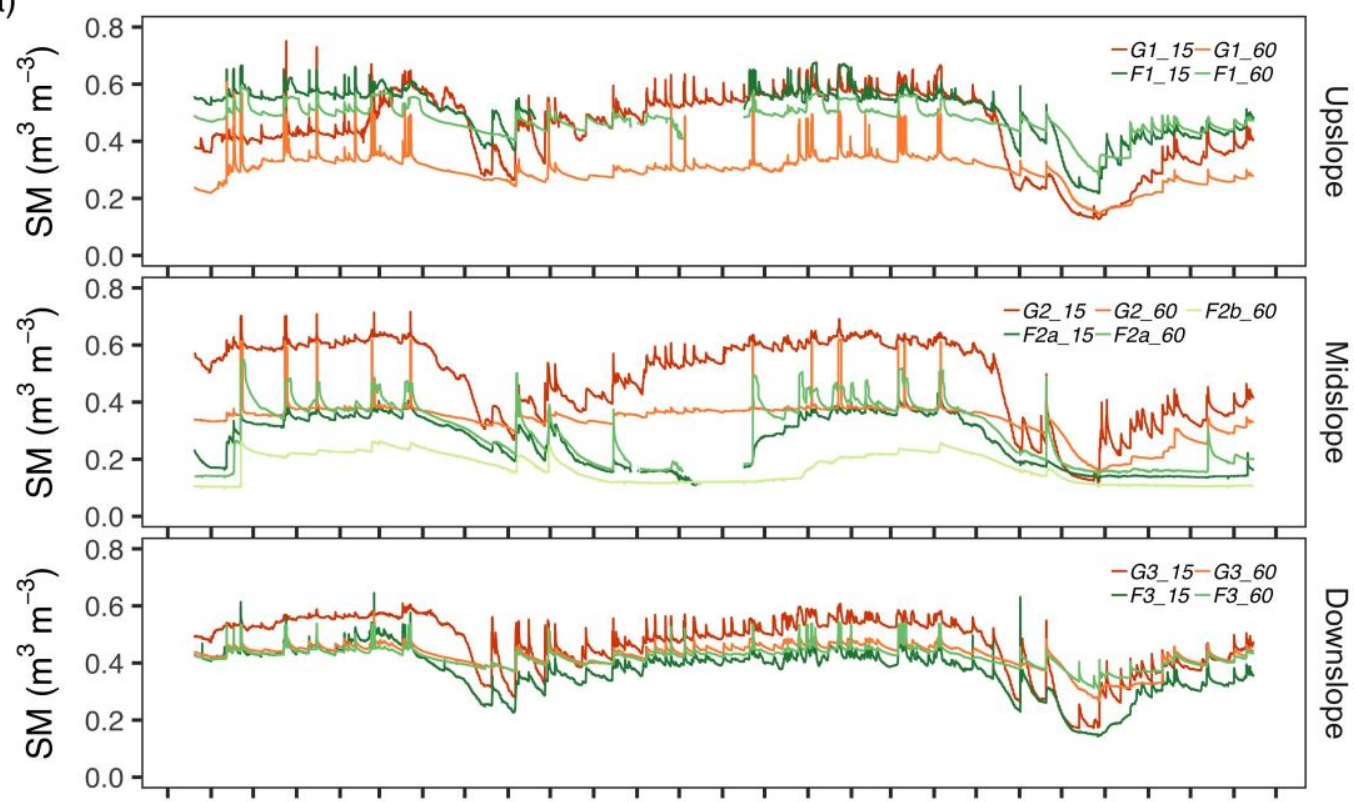

b)

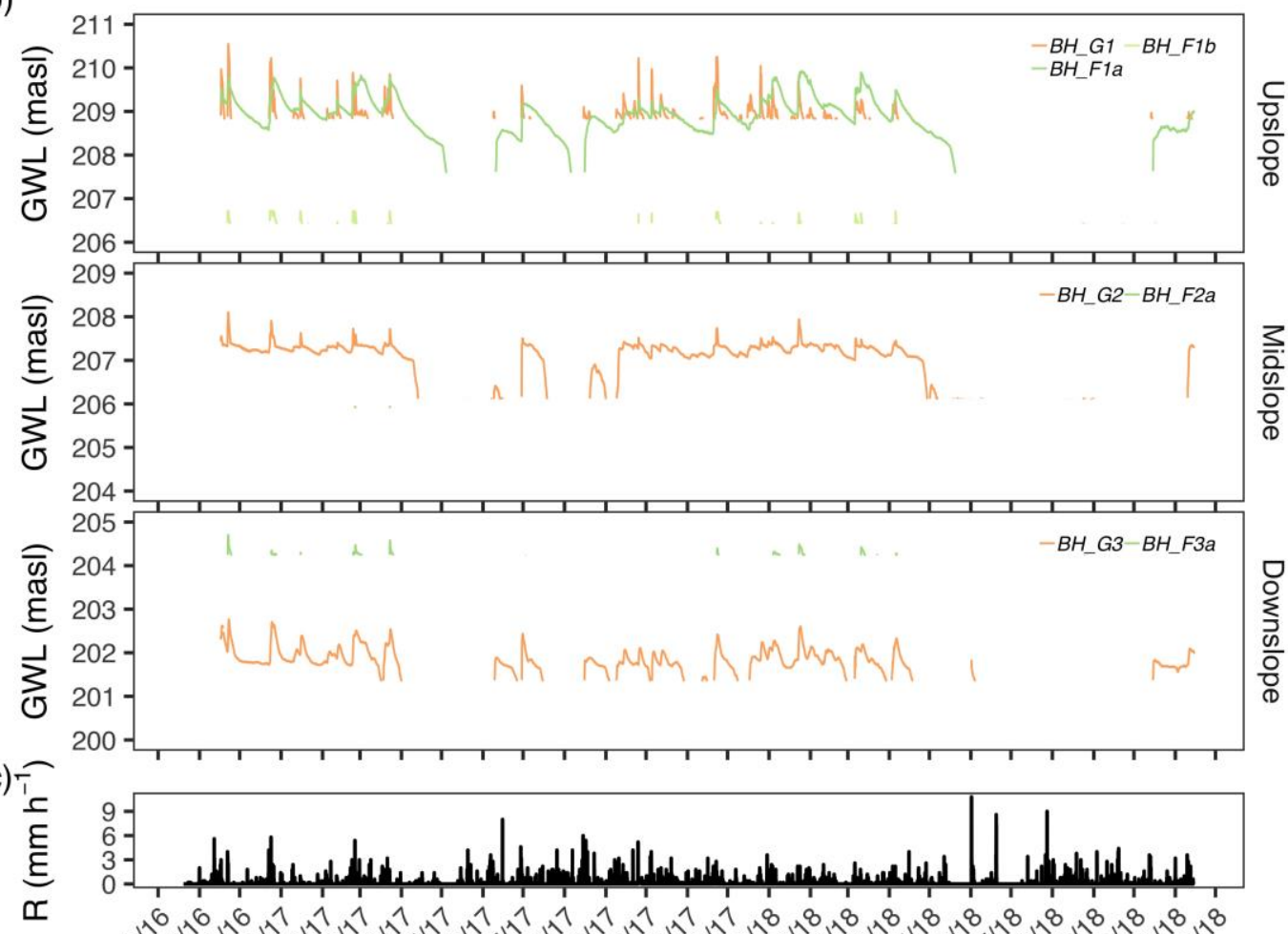

Date (month/year 
Over seasonal timescales there was generally more variability in soil moisture content at $0.15 \mathrm{~m}$ depth compared to at $0.6 \mathrm{~m}$ depth, apart from in the forest strip, where seasonal variability was similar in both shallow and deeper soil depths. This deeper and prolonged drying of the forest soils in summer and autumn has implications for soil water storage potential. For the whole time series, cumulative soil moisture content was $72-75 \%$ and $81-96 \%$ compared to a baseline of cumulative median winter soil moisture content for all sensors in the forest (F2 sensors) and all sensors on grassland respectively. An example of this contrast between two sensors is shown in Figure 4. Most of the estimated 15\% 'additional' storage capacity in the soil beneath the forest strip occurred in the three months September-November. This is likely to be an underestimate of the actual storage, or the additional storage available in winter, because saturation was not observed in the forest soils during the study period.

Figure 4: Soil moisture content at $60 \mathrm{~cm}$ depth under forest (F2a_60) and grassland (G2_60) and for the entire study period compared to the baseline of the median winter soil moisture content for each sensor (horizontal lines). Highlighted areas are the soil moisture deficit in summer/autumn months, indicating the potential soil moisture storage. 


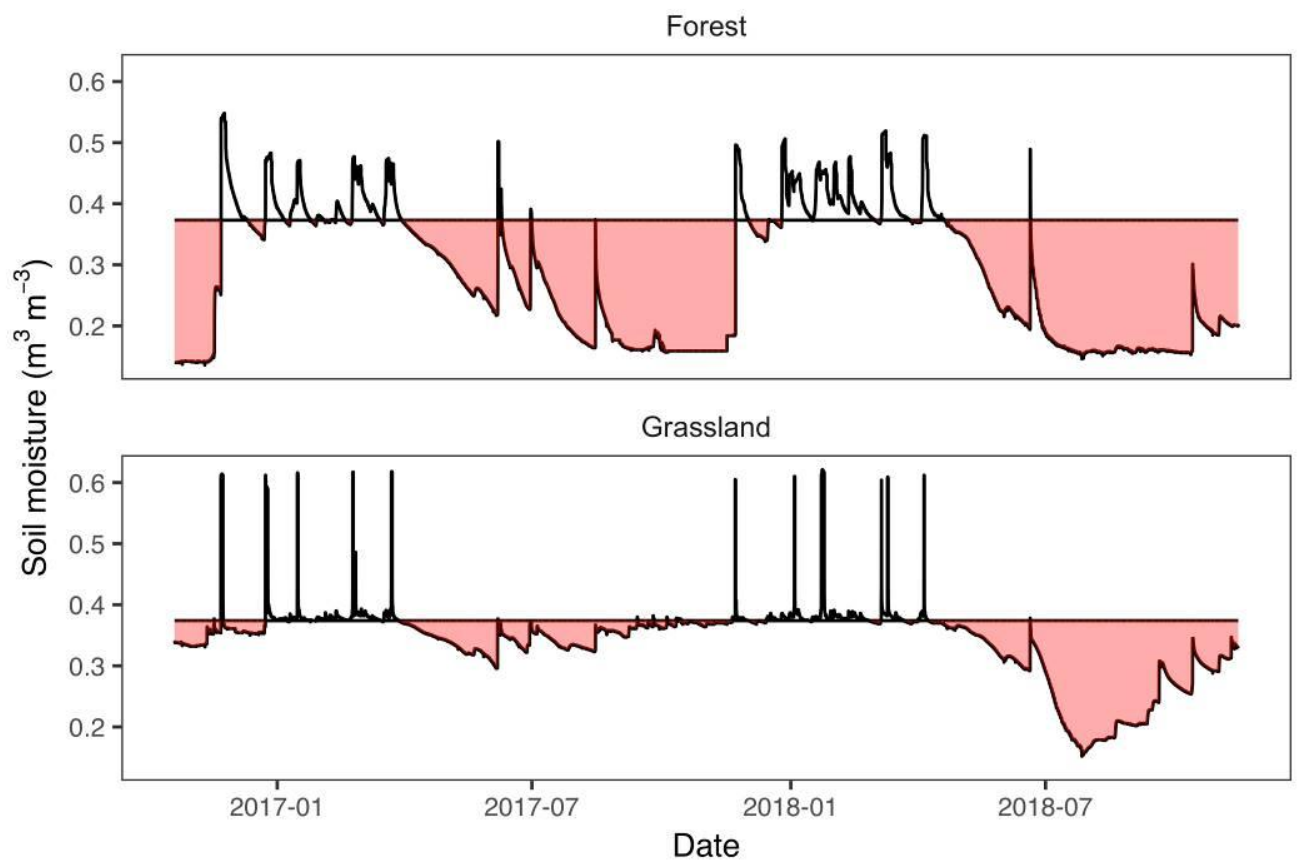

Groundwater data were discontinuous at the depths of all the hillslope piezometers. A water table was recorded for much of the study period on the grassland transect and in the upslope part of the forest transect. It was highest during winter but disappeared from all piezometers during mid-summer, with a range of over $2 \mathrm{~m}$ in some piezometers. In three of the four piezometers with the most continuous data, the water table showed bi-modal recession behaviour, with an abrupt drop in water table depth below a threshold level of $1.87 \mathrm{~m}$ below ground level in $\mathrm{BH} \_\mathrm{F} 1 \mathrm{a}, 1.50 \mathrm{~m}$ in $\mathrm{BH} \_\mathrm{G} 2$ and $2.48 \mathrm{~m}$ in $\mathrm{BH} \_\mathrm{G} 3$ (Figure 3). This is indicative of layered geology with large contrasts in permeability between layers, probably representing the transition from less permeable glacial till to unconsolidated gravelly head deposits or weathered rock head. 


\subsubsection{ERT survey data}

\section{Resistivity structure along transects}

The resistivity surveys give insights into the geological structure of the hillslope, with a layered structure visible on both transects (an example is given in Figure 5 and the same structures are visible in Figure S2). Outside the forest strip the topmost layer (0-0.5 m) on both transects had lower resistivities in winter and higher resistivities in summer. This layer corresponds with more organic rich soil according to the borehole logs and soil pits, and sits on a much higher resistivity layer $(0.5-1.7 \mathrm{~m})$ that corresponds with glacial till (Table S1, Figure S1). Below $1.7 \mathrm{~m}$ depth, resistivities decreased again, probably due to the presence of a water table in many of the grassland areas on both transects, as the borehole logs do not indicate a significant change in geological properties at this depth. The upslope part of the grassland transect differed from other grassland areas, with higher resistivities below a depth of $0.5 \mathrm{~m}$. The resistivity structure was different in the forested area, with less obvious layering and high resistivities to the bottom of the section.

Figure 5: Resistivity cross section for the grassland (foreground) and forest (background) transects in November 2016. 


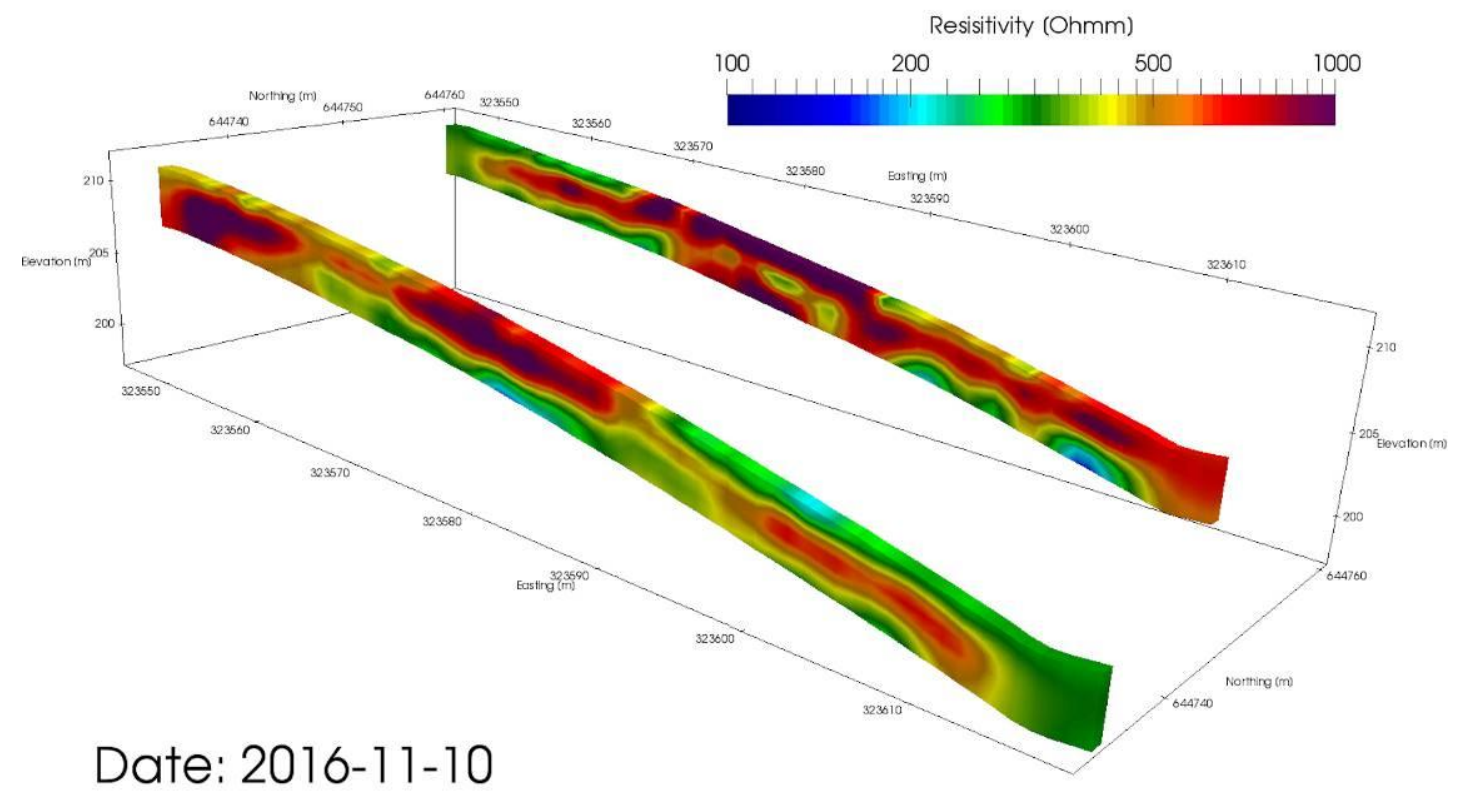

\section{Resistivity variation with depth and time along transects}

The time-lapse ERT data indicate that the variation in resistivity across the ten surveys generally decreased with depth on both transects and at all slope locations (Figure 6). However, variability was greater on the forest transect, particularly to $1.7 \mathrm{~m}$ depth within the midslope forest strip area. In this zone interquartile range (IQR) of the relative resistivities was 4.0-16.8 \% for the forest and 2.5-6.8 \% for the adjacent grassland. Within the first $12 \mathrm{~m}$ downslope of the forest, there was also greater variation in relative resistivities in the top $1.7 \mathrm{~m}$ depth compared to the adjacent grassland and compared to similar locations upslope of the forest. In this zone the IQR of the relative resistivities was $6.71-12.7 \%$ for the forest and 1.7$10.2 \%$ for the adjacent grassland (Figure 6).

The ERT time series data give further insight into the changing seasonal impact of the forest strip on hillslope subsurface hydrological dynamics along the hillslope (Figure 7). In the upslope domain, resistivities displayed similar seasonal patterns on both transects. They were higher in 
the drier summer surveys compared to the autumn, winter and spring surveys, with the amplitude of the changes decreasing with depth, and little variation below $2.5 \mathrm{~m}$.

The largest differences between transects were in the midslope area. The absolute changes in resistivity between surveys were more pronounced in the midslope forest domain than in the grassland, implying more extreme wetting and drying of the subsurface below the forest strip. The forest area also remained more highly resistive later into the year (through the autumn surveys). This effect was minimal below $2.5 \mathrm{~m}$ and insignificant below $3.4 \mathrm{~m}$.

The seasonal pattern of changes in resistivity was similar in the downslope domain to the upslope domain, with higher relative resistivities in the summer surveys and lower resistivities in the autumn, winter and spring surveys. There is no indication that the prolonged subsurface drying into the autumn beneath the forested area extended downslope of the forest strip. As in the upslope and midslope domains, the amplitude of seasonal changes decreased with depth on both transects.

Figure 6: Resistivity variation at different depths along the two transects for the 10 surveys conducted between November 2016 and April 2018 relative to the May 2017 survey (horizontal line at 0 ). The forested area is located within the midslope domain. The horizontal line inside the box represents the median and the lower and upper hinges correspond to the first and third quartiles. The upper and lower whiskers depict the largest and smallest values respectively within 1.5 * the interquartile range (IQR). Outliers removed for clarity. $x$-axis labels represent range of cells (as distance along the transect) used to calculate statistics - e.g. $[0,4)$ indicates the first four model cells on the line between 0-1,1-2, 2-3 and 3-4 $\mathrm{m}$. 


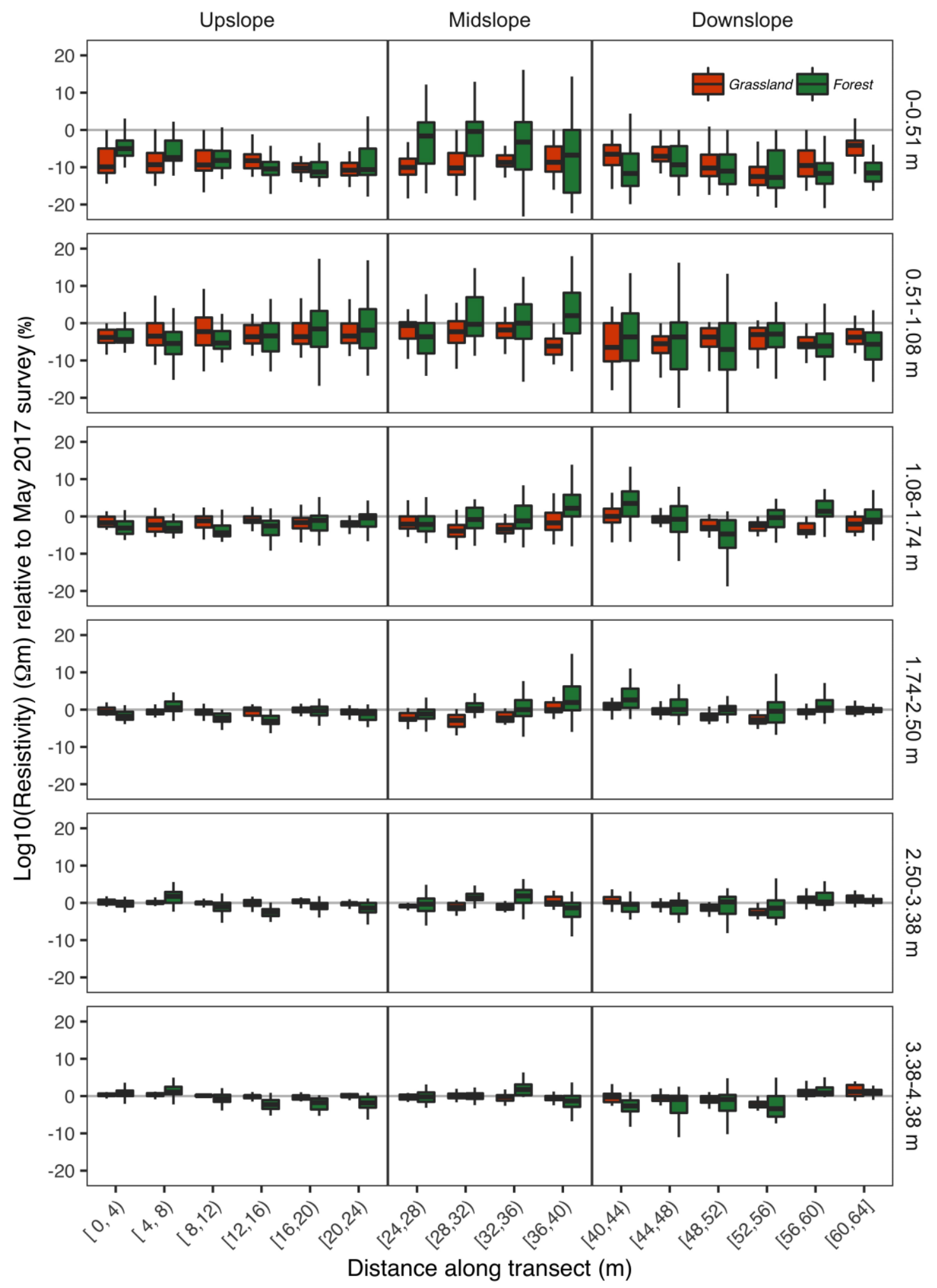

Figure 7: Median resistivities for each transect across different domains and depths for the 10 surveys conducted between November 2016 and April 2018 relative to the May 
2017 survey (horizontal line at 0 ). The forested area is located within the midslope domain. Median resistivities for each survey are calculated from cells across the whole domain (i.e. 0-24 $\mathrm{m}$ for the upslope domain, 24-40 $\mathrm{m}$ for the midslope domain, and $40-64$ m for the downslope domain). Shading represents $95 \%$ confidence intervals.

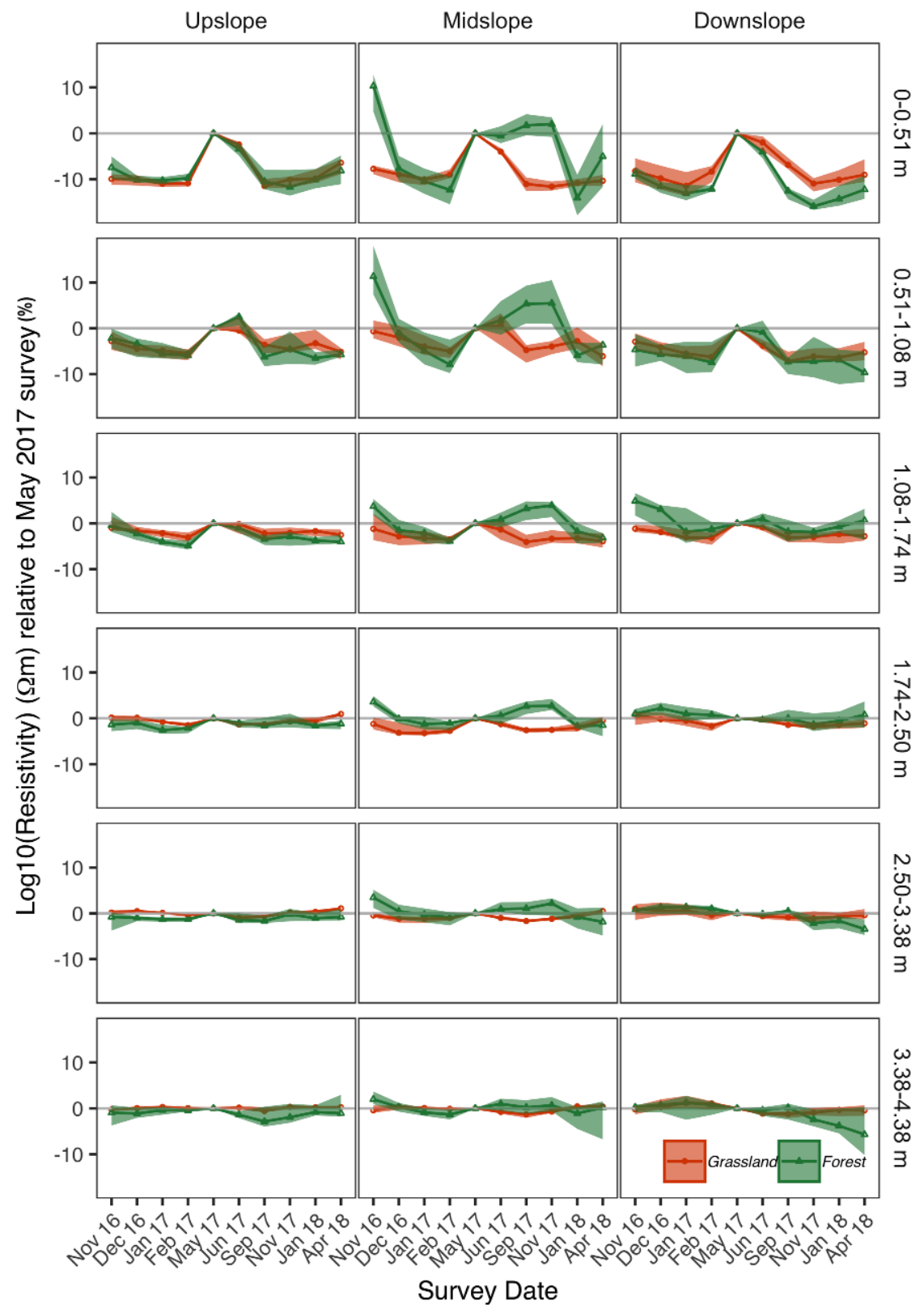




\subsection{Event-scale dynamics}

\subsubsection{Differences in subsurface hydrology response between hillslope locations}

The number of sensors responding decreased consistently with depth in each domain from the soil moisture sensors at 0.15 and $0.6 \mathrm{~m}$ depths to the groundwater sensors at $\sim 2.5 \mathrm{~m}$ depth (Figure 8). However, there were significant differences in the number responding between transects at different locations on the hillslope, when comparing sensors at all depths in each domain. The most significant difference in the number responding was in the midslope domain $(p<0.001) .66 \%$ of grassland sensors in the midslope domain responded over the 52 events, whilst only $31 \%$ responded in the forest strip. Much of the relative decrease in the forest domain was due to fewer of the $0.15 \mathrm{~m}$ (particularly in summer) and $2.5 \mathrm{~m}$ sensors responding (Figure 8). There was less difference in number responding between the transects in the upslope domain (58\% and $74 \%$ responded for forest and grassland respectively) and downslope domain (62\% and $69 \%$ responded for forest and grassland respectively). Some of the difference in the upslope domain can be explained by events not being logged as responses due to soil saturation prior to the event for three events at location F1_60 and one event at F1_15. 
Figure 8: Number of sensors responding (\%) across all rainfall events $(n=52)$ for all working soil moisture and groundwater sensors at different depths and domains on the forest strip and grassland transects for Winter/Spring (Wi/Sp) and Summer/Autumn $(\mathrm{Su} / \mathrm{Au})$ seasons.

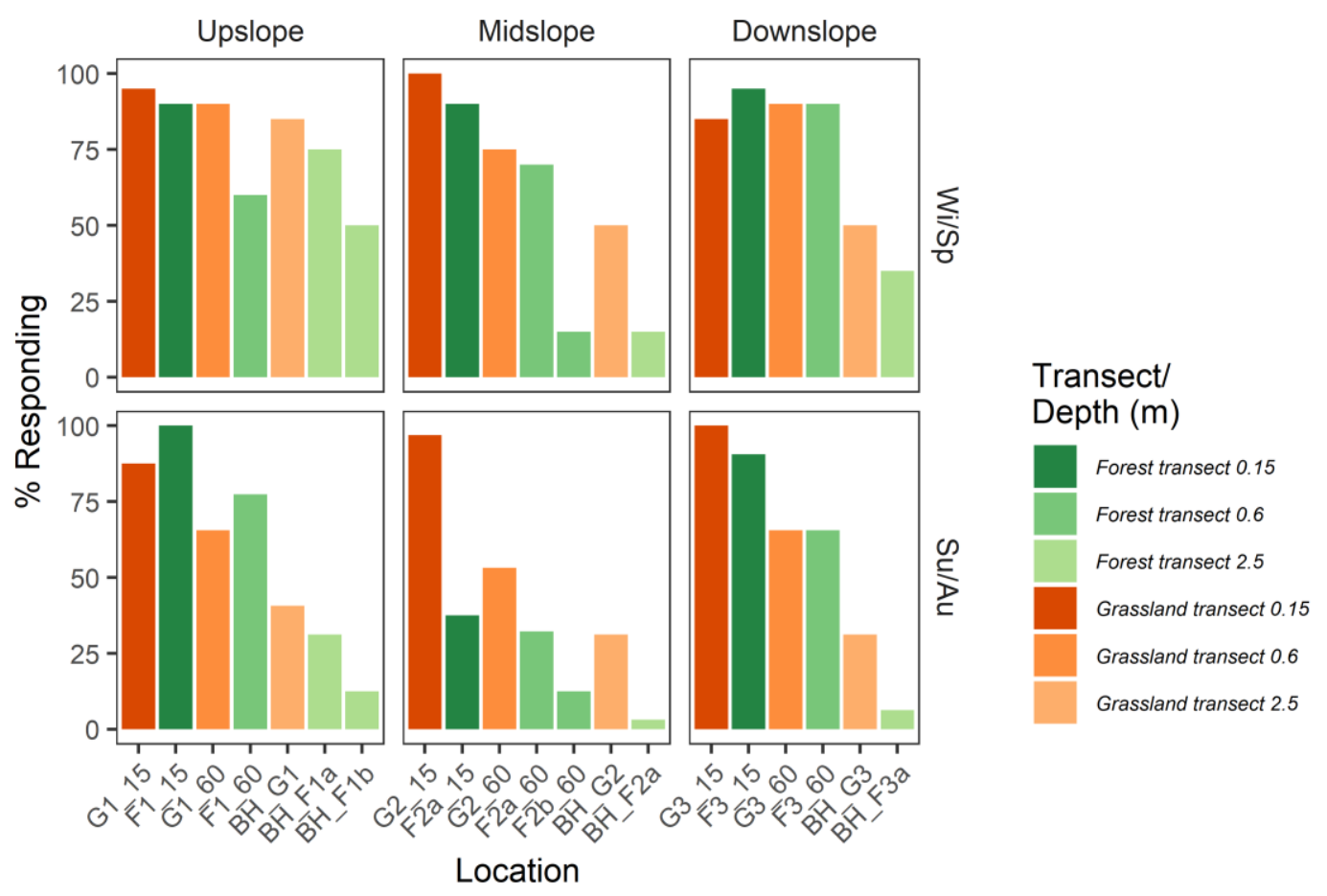

Comparing data from the nine events when most of the sensors responded, the time taken for sensors to respond (TTR) increased with depth in all domains and there was no significant difference in TTR between forest and grassland transects at any location or depth (Figure 9). However, TTR increased downslope for the piezometers, with significant differences between upslope and downslope locations $(p<0.05)$, but not for the soil moisture sensors (Figure 9 ). The pairwise comparison of all events ( $n=52$ ) additionally indicates that there were no significant differences in TTR between summer and winter at any location, although summer TTRs were slightly more variable than winter TTRs (Figure S3). 
Figure 9: Time to response from the start of rainfall (TTR) for the different domains and depths on the forest strip and grassland transects during nine rainfall events when the borehole downslope of the forest responded and the majority of the other soil moisture and groundwater sensors responded. The horizontal line inside the box represents the median and the lower and upper hinges correspond to the first and third quartiles. The upper and lower whiskers depict the largest and smallest values respectively within 1.5 * the interquartile range (IQR). Numbers in italics show the number of events in which sensor responded. Dots are outliers.

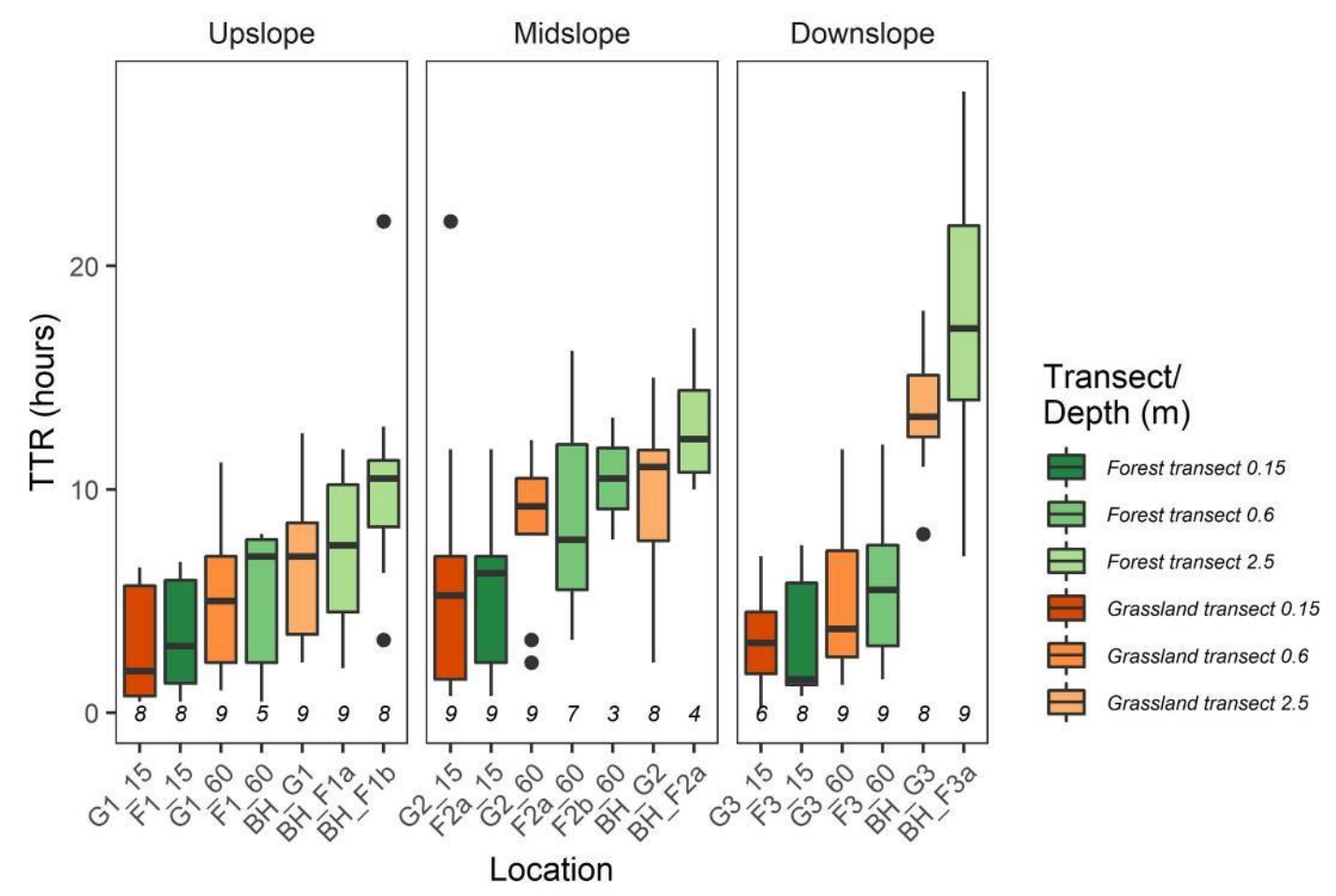

The time that sensors took to reach peak soil moisture/water table from start of rainfall (TTPR) and the maximum rise (MR) were much more variable at individual sensors and between sensors, especially during the subset of nine events in wetter conditions (Figure S4a). This was mainly due to the rapid occurrence of saturation in some of the $0.6 \mathrm{~m}$ sensors. However, there appears to be a similar pattern to that seen in the TTR data, of increasing water table TTPR downslope but no systematic increase in soil moisture TTPR. The pairwise comparison of all 52 
events suggests that TTPR was seasonally variable, especially in the forested midslope domain. In summer, the TTPR interquartile range for all forest locations was 13-16 hours, compared to 6-11 hours for the adjacent grassland) (Figure S4b).

\subsubsection{Relationships between event characteristics and subsurface hydrology response metrics}

Total event rainfall and the 5-day AWI are good predictors of overall number of sensors responding $(p<0.001)$. There are also significant seasonal differences, with the log odds of response much less likely in summer/autumn compared to the winter/spring $(p<0.001)$. Comparison between transects, depths and domains reveals a more complex picture. Total event rainfall and seasonal differences are significant explanatory factors for whether sensors respond to events in most locations (Figure 10). However, event characteristics and seasonal variation in conditions have less impact on the response of the $0.15 \mathrm{~m}$ soil moisture sensors, because these respond easily across the whole range of events. The $0.15 \mathrm{~m}$ sensor in the forest strip is an exception, where response seems to be significantly affected by total event rainfall and there are significant seasonal differences (in summer/autumn compared to winter/spring) compared to grassland areas. Total event rainfall appears to have a more significant impact on the number of the $0.6 \mathrm{~m}$ and $2.5 \mathrm{~m}$ sensors that respond in most locations, presumably because a threshold level is required for these to respond. The seasonal variation in these deeper sensors is less clear than at shallower levels, but there are similar patterns between $0.6 \mathrm{~m}$ sensors on the forest and grassland lines, with significant differences between summer/autumn, compared to winter/spring on the forest transect. These differences are consistent with seasonal changes in soil moisture being more marked in the forest strip, with a later onset of sensor response. 
Figure 10: Graphical representation of significance levels from logistic regression of the number of soil moisture and groundwater sensors responding for different transects, domains and depths for different independent variables across all 52 rainfall events. Spring, Summer and Autumn are based on logistic regression comparisons to Winter. Dashed grey line highlights significance level of $p=0.05$.

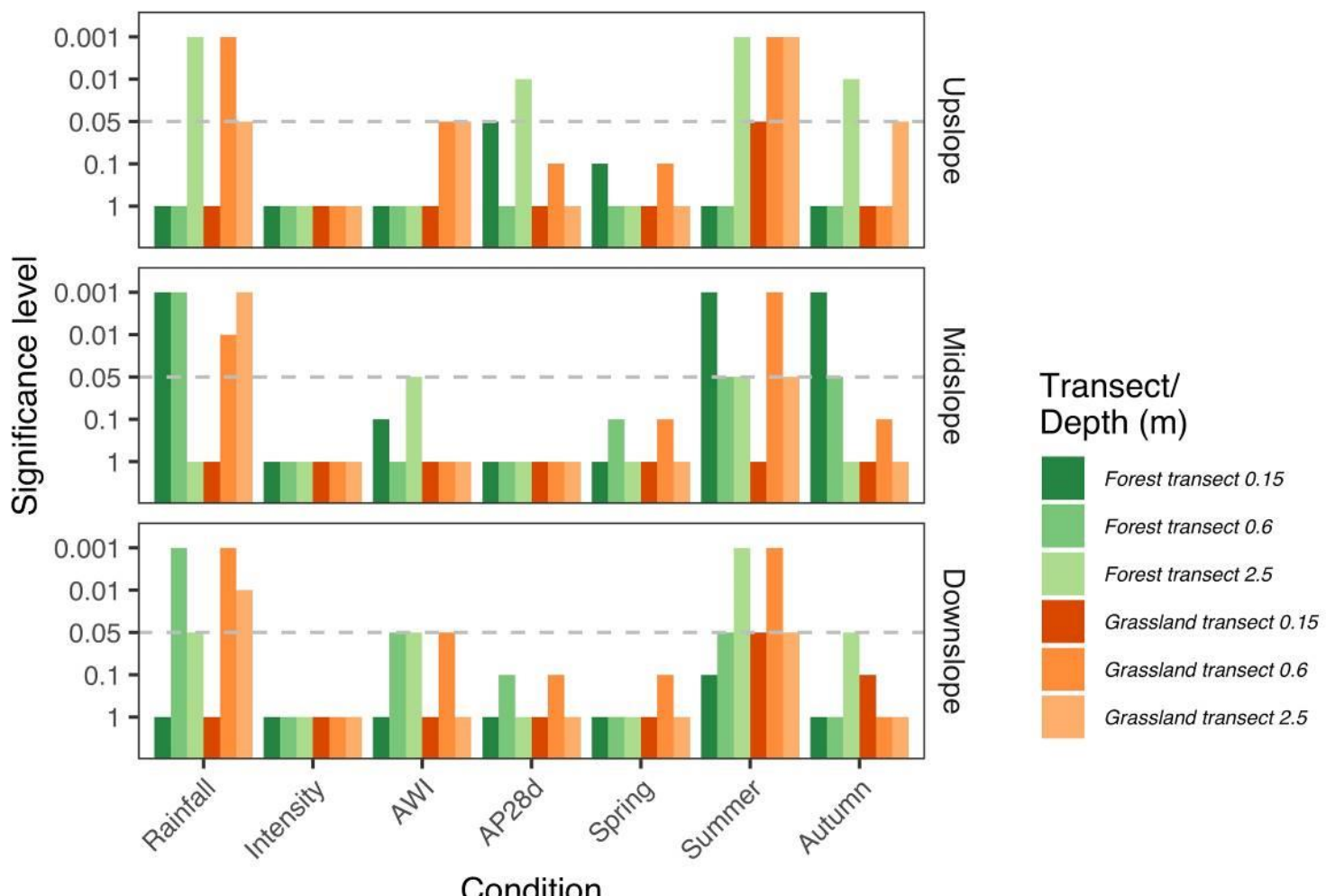

Correlation of event characteristics and response metrics at individual locations showed some significant correlations but no clear pattern could be identified between transects. Correlation coefficients calculated for data for all sensors across both transects showed more generally that total event rainfall appears to be the most important factor controlling MR for both soil moisture sensors and piezometers. Event intensity also appears to be a significant control on TTR and TTPR for both soil moisture sensors and piezometers. Finally, in winter the 5-day AWI appears to be an important factor in controlling the rate of response of the piezometers and AP28d for the maximum rise in the soil moisture sensors (Table S4). 


\section{Discussion}

\subsection{Forest influence on soil moisture and groundwater dynamics}

beneath the forest strip

4 Pronounced differences in subsurface hydrology characteristics and dynamics were

5 identified between the forest strip area and the grassland areas on both transects from

6 the 2-year monitoring programme based on soil moisture, groundwater and time-lapse

7 ERT measurements. These observations have been used to infer the hydrological

8 processes operating in the hillslope and to devise the conceptual model of these

9 described below.

11 The forested area had lower absolute but more variable soil moisture content, higher

12 relative ERT resistivities, a considerably lower water table and less event-driven

13 response of subsurface sensors. In the zone above the water table and within the

14 rooting depth of the trees $(\sim 2.5 \mathrm{~m})$, there were reductions in soil moisture levels and in

15 the numbers of sensors responding during events, that extended later into the autumn

16 compared to the grassland. The ERT data show the same seasonal effects and

17 additionally suggest these were contained within the boundaries of the forest.

19 Our conceptual model to explain these findings is shown in Figure 11. We hypothesise that the differences between the grassland (Figure 11a) and the forest strip (Figure 11b) can be attributed to a combination of greater evapotranspiration and canopy interception

22 by trees, and the likely increased infiltration rate of the forest soils and sub-soils due to

23 more extensive rooting systems and their effects on hydraulic conductivity. Studies in the

24 UK have found that interception losses can range between 25 and $50 \%$ of precipitation,

25 with greater losses for summer events and the interception fraction decreasing with 
increasing rainfall (Johnson, 1995). Conifers and broadleaves can also lose an additional 300-390 $\mathrm{mm} \mathrm{yr}^{-1}$ through transpiration (Nisbet, 2005). These findings provide indirect evidence to explain the differences in response of the forest sensors between seasons, sporadic responses during larger summer rainfall events and the delayed 'wetting up' of the forest soils until the onset of larger rainfall events in the late autumn when some trees had also lost their leaves. Median soil hydraulic conductivities in the forest are likely to range from $42-174 \mathrm{~mm} \mathrm{~h}^{-1}$, based on results from a study investigating similar hillslopes and land uses in the same catchment, which found that tree rooting systems played a significant role in controlling hydraulic conductivity (Archer et al., 2013). We also found that while there were similarities in the soil matrix and horizon depths under the forest and grassland areas, there were differences in rooting systems, with larger roots and deeper rooting systems in the forest compared to the grassland. These differences in hydraulic conductivity likely contribute to the observed lower absolute soil moisture levels in the forest, higher resistivities and the lower water table.

At depths greater than $2.5 \mathrm{~m}$ there were no significant observable seasonal impacts of the forest on moisture dynamics (Figure 11b). Piezometer data from the rainfall events indicate that the water table was within $2.5 \mathrm{~m}$ of the ground surface for the wettest periods in the year, probably attenuating the seasonal variations in resistivity observed at shallower depths. The zone below $2.5 \mathrm{~m}$ is also likely to be at the limit of the rooting depths of the trees, reducing their impacts on both evapotranspiration and hydraulic conductivity. The lower water table in the forest strip compared to the grassland is one of the most striking differences between the transects (Figure 11). We suggest that this is due to enhanced hydraulic conductivity within forest soils and sub-soils, rather than

50 'pumping' by trees as the effect persists through the winter when evapotranspiration and 51 interception are greatly reduced. 
52 Figure 11: Conceptual model showing the hillslope with (a) the across-slope forest

53 strip and (b) the grassland transects. The major hydrological fluxes are shown in

54 relation to hillslope, land cover and geological structure, with arrow size relating

55 to the size of the flux. ET: evapotranspiration; P: precipitation; TF: throughfall; I:

56 infiltration. Dashed purple lines in (a) delineate zones of differing moisture

57 dynamics in the forest transect: A) zone within rooting depth of trees ( 2.5 $\mathrm{m})$ with

58 greater variability in soil moisture, extended seasonal reduction in soil moisture

59 and reduction in event-driven response of sensors; B) zone below rooting depth

60 of trees and with seasonal water table that attenuates seasonal variation in

61 moisture dynamics observed at shallower depths; and C) zone with greater

62 variation in moisture dynamics (inferred from ERT data) due potentially to deeper

63 unsaturated zone and wind shadow effect close to trees. Depths of zones are not

64 drawn to scale.

65

66

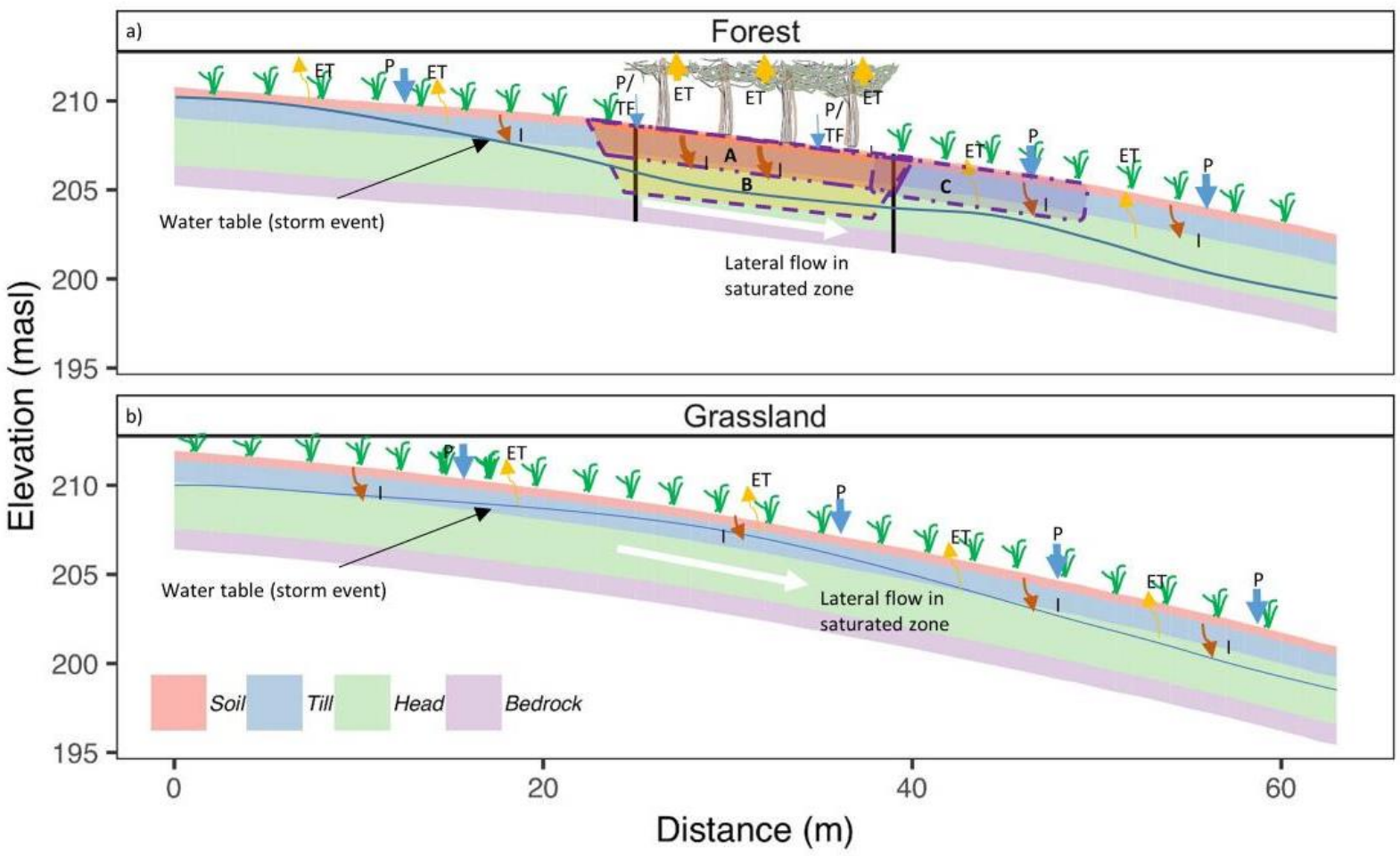


67 These results are consistent with studies at the hillslope scale on the effects of forest

68 planting on soil moisture dynamics. Significant increases in hydraulic conductivity in

69 forest soils have been reported (Archer et al., 2013; Carroll et al., 2004; Ghestem et al.,

70 2011; Wheater et al., 2008), although few studies have examined directly how variations

71 in hydraulic conductivity due to trees affect groundwater levels across hillslopes. Others

72 have demonstrated the seasonal depletion of soil moisture content and groundwater

73 levels due to forest evapotranspiration (Bonell et al., 2010; Greenwood and Buttle,

74 2014), but there is considerable variability depending on canopy structure, climate and

75 soil and vegetation characteristics (Guswa, 2012). Similar effects of forest planting and

76 removal have been described at the catchment scale, with afforestation/reforestation

77 often leading to a reduction in annual water yield (Bosch and Hewlett, 1982; Brown et

78 al., 2005; Filoso et al., 2017). Recent meta-analysis of the results of catchment studies

79 worldwide has shown the importance of subsurface storage substrate porosity,

80 permeability and unsaturated zone depth, and its relationship to forest cover (Evaristo

81 and McDonnell, 2019) in modulating annual water yield.

82

4.2 Forest influence on downslope soil moisture and groundwater dynamics

While the forest strip had measurable impacts on the subsurface hydrological conditions beneath the forest, no significant effects were observed downslope in the zone above

87 the water table (<2.5 $\mathrm{m}$ depth). There were no significant differences between transects

88 in long-term median soil moisture content or variability at the downslope soil moisture

89 sensors at $0.15 \mathrm{~m}$ and $0.6 \mathrm{~m}$ depth. For the same sensors there was no significant

90 difference in rainfall event metrics. In the ERT data, the more extreme seasonal variation

91 and prolonged summer/autumn drying that was observed beneath the forest at depths of

$92<2.5 \mathrm{~m}$ was not observed in the hillslope portions downslope of the forest, even in areas 
very close to the forest ( $<2 \mathrm{~m}$ from the forest boundary). As shown in Figure 11, we suggest that the forest has only limited seasonal influence on shallow moisture dynamics. We attribute this mainly to the dominance of vertical processes (evapotranspiration and drainage) in the unsaturated zone as in other areas of the slope, as well as the continued infiltration and percolation of any surface and shallow subsurface flow as it moves downslope (Klaus and Jackson, 2018).

\section{These findings notwithstanding, the forest did appear to depress groundwater depths} downslope. During the wettest periods, groundwater depths were up to $1.7 \mathrm{~m}$ lower downslope of the forest compared to depths upslope of the forest, and up to $1.5 \mathrm{~m}$ lower compared to similar locations on the grassland transect. However, there is evidence that groundwater connectivity existed between the areas upslope and downslope of the forest during larger events. Time to response in the $0.15 \mathrm{~m}$ and $0.6 \mathrm{~m}$ soil moisture sensors was similar at all locations on the slope, but increased downslope for the piezometers. These longer response times downslope than upslope in the piezometers are interpreted as an indication that lateral flow processes from upslope to downslope are more important than vertical infiltration in driving groundwater dynamics in this part of the slope and in moving water down the slope through a connected shallow groundwater system. This implies that the forest does not 'interrupt' lateral downslope water table connectivity during larger events. This is consistent with findings from studies on catchment scale hydrological connectivity and threshold behaviour (Detty and McGuire, 2010a, 2010b; McNamara et al., 2005).

Lastly, the ERT data show that while median relative resistivities across all surveys were similar between transects in the downslope area, they were more variable at shallow depths $(<1.7 \mathrm{~m})$ in the first $12 \mathrm{~m}$ downslope of the forest strip, compared to the adjacent 
119 grassland and similar locations upslope of the forest strip. This may be indicative of a

120 seasonally variable deeper unsaturated zone in the area immediately downslope of the

121 forest with less attenuation of resistivity due to the seasonal water table. The south-

122 westerly prevailing wind and the north-south orientation of the forest strip means that a

123 rain shadow effect from the forested area could also contribute to such variability. This

124 effect has been observed to extend to $\sim 6 \mathrm{~m}$ on to adjacent grassland at sites with similar

125 height trees in the UK, particularly in winter when frontal rainfall is accompanied by

126 stronger winds (Wheater et al., 2008).

127

\section{$128 \quad 4.3$ Implications for flood risk management}

129 Our study suggests that in temperate environments forest boundary strips could

130 marginally increase catchment storage due to evapotranspirative 'pumping' and

131 interception by trees that extends to deeper depths and is more prolonged than in

132 grassland areas. However, our results show that this additional subsurface moisture

133 storage is highly restricted in space to the area in and around the forest itself. This effect

134 is greatest in summer and autumn, so may have a mitigating effect on summer flood events, but additional storage capacity is likely to be limited in winter and spring. Such effects are also likely to vary with forest type and age, as discussed in other studies

137 (Archer et al., 2013; Chandler et al., 2018; Jipp et al., 1998). Given that flood events 138 commonly have higher frequencies in summer in small catchments in Scotland (Black 139 and Werritty, 1997) and in the immediate region of this study (Masson, 2019), additional

140 subsurface moisture storage provided in summer by forest strips may provide some

141 benefit depending on storm characteristics and antecedent conditions.

143 At the storm event timescale, our results suggest that forest strips locally decrease the 144 responsiveness of soils and groundwater beneath the forest strip to rainfall events, 
145 especially in summer/autumn. During larger rainfall events and in winter, forest soils

146 respond similarly to rainfall events and at similar rates as grassland, but appear to

147 saturate less frequently, suggesting that forest strips could reduce runoff through

148 combined effects of intra-event evaporation and more rapid drainage to the subsurface.

149 This is aligned with reported increased hydraulic conductivity and porosity in soils below

150 forest strips (Carroll et al., 2004; Wheater et al., 2008).

151

152 From this study, the spatial influence of forest strips appears to be slightly larger than

153 their width, with some downslope depression observed in soil moisture content and

154 groundwater levels. In slopes with much less permeable soils or compacted soils, the

155 forest may act more like a "French drain", channelling water into deeper layers.

156 However, the effectiveness of such a system would be limited by the connectivity of the

157 'drain' to deeper, more permeable substrate, or to more permeable areas laterally, and

158 to the permeability of soils/geology downslope. On its own the limited storage capacity of

159 the strip would be quickly overwhelmed if surrounded by a less permeable system. This

160 highlights the highly context-specific nature of the impacts of forest strips on subsurface

161 moisture storage and on the attenuation effects of increases in hydraulic conductivity.

163 The role of water table connectivity and its links to threshold behaviour in catchment

164 response is increasingly recognised in the hydrological literature (Bracken et al., 2013;

165 Detty and McGuire, 2010a). This study suggests that the forest strip has little impact on

166 groundwater connectivity during larger events, implying that similar upland landscapes

167 with fragmented forest strips might have limited impact on groundwater dynamics at the

168 event timescale and in wetter periods. There is need for further investigation to assess whether there are optimal soil and geological conditions, and extents and locations of 
170 forest cover that might have a larger influence at the catchment scale, as has been

171 suggested in other environments (Ilstedt et al., 2016).

172

1734.4 Conclusions

174 Forest strips are being used around the world for reduction of flood risk. Nevertheless,

175 our knowledge of how forest strips impact runoff in general and local- and down-gradient

176 hydrological conditions, is still poor. This study examined the impact of an across-slope

177 forest strip on sub-surface soil moisture and groundwater dynamics. We found that an

178 increase in soil moisture storage potential associated with the forest strip was highly

179 seasonal and did not extend much beyond the forest strip itself. In this temperate

180 climate, during wetter winter periods, when widespread runoff is typically highest,

181 isolated strips of forest like the one we studied are likely to have only a marginal impact

182 on sub-surface moisture storage. However, in specific contexts, such as lower

183 magnitude events or intense summer storms, forest strips could locally reduce

184 catchment responsiveness to storm events. This study only considered sub-surface

185 processes; the impacts of forest strips on surface runoff, for example through increased

186 roughness and infiltration, could be greater.

187

188 Our study showed the utility of time-lapse ERT for extrapolating findings from point-

189 based measurements along hillslopes and to greater depths in terrain that is difficult to

190 instrument invasively. ERT helped to show the larger, longer and deeper seasonal

191 changes in soil moisture in the forest compared to adjacent grassland, as well as

192 providing insight into the lateral variability of moisture changes within the transects.

193 Higher frequency ERT data that is now available at daily or sub-daily time-steps

194 (Chambers et al., 2014) would be a useful extension to this study to further

195 understanding of subsurface hydrological dynamics at the storm event scale. 


\section{Acknowledgements}

197 We would like to thank the landowner for giving us access to the site and the Tweed

198 Forum for their help in identifying suitable sites within the wider Eddleston Natural Flood

199 Management project. We would also like to thank Robert Fairhurst, Adam Francis,

200 Anthony Newton, Kirsty Shorter, Heiko Buxel and Jez Everest for their help with

201 fieldwork.

202

203 Funding: This work was supported by L. Peskett's NERC E ${ }^{3}$ DTP /BGS BUFI PhD

204 studentship at the University of Edinburgh, UK (grant number NE/L002558/1) and

205 associated NERC Research Experience Placement grant to R. Fairhurst; a University of

206 Edinburgh Innovation Initiative Grant (grant number GR002682); a SAGES Postdoctoral

207 \& Early Career Researcher Exchange (PECRE) grant supporting collaboration with J.

208 McDonnell; and in-kind contributions and loan of equipment from the School of

209 GeoSciences, University of Edinburgh and BGS Edinburgh and Keyworth offices.

210 


\section{References}

212 Archer, N.A.L., Bonell, M., Coles, N., MacDonald, A.M., Auton, C.A., Stevenson, R., 213 2013. Soil characteristics and landcover relationships on soil hydraulic 214 conductivity at a hillslope scale: A view towards local flood management. J. $215 \quad$ Hydrol. 497, 208-222. https://doi.org/10.1016/j.jhydrol.2013.05.043

216 ASTM international, 2004. Standard test methods for particle-size distribution (gradation) 217 of soils using sieve analysis. ASTM International.

218 Auton, C., 2011. Eddleston Water Catchment, Superficial Geology, 1: 25000 Scale.

219 Bachmair, S., Weiler, M., 2012. Hillslope characteristics as controls of subsurface flow 220 variability. Hydrol. Earth Syst. Sci. 16, 3699-3715.

Ball, D.F., 1964. Loss-on-ignition as an estimate of organic matter and organic carbon in 222 223 non-calcareous soils. J. Soil Sci. 15, 84-92. https://doi.org/10.1111/j.13652389.1964.tb00247.x

224

Black, A.R., Werritty, A., 1997. Seasonality of flooding: a case study of North Britain. J. Hydrol. 195, 1-25. https://doi.org/10.1016/S0022-1694(96)03264-7

Bonell, M., Purandara, B.K., Venkatesh, B., Krishnaswamy, J., Acharya, H.A.K., Singh, U.V., Jayakumar, R., Chappell, N., 2010. The impact of forest use and reforestation on soil hydraulic conductivity in the Western Ghats of India: Implications for surface and sub-surface hydrology. J. Hydrol. 391, 47-62. https://doi.org/10.1016/j.jhydrol.2010.07.004

231 Bosch, J.M., Hewlett, J.D., 1982. A review of catchment experiments to determine the effect of vegetation changes on water yield and evapotranspiration. J. Hydrol. 55, 3-23. 
234 Bracken, L.J., Wainwright, J., Ali, G.A., Tetzlaff, D., Smith, M.W., Reaney, S.M., Roy,

235

236

237

238

239

240

241

242

243

244

245

246

247

248

249

250

251

252

253

254

255

256

257

258

A.G., 2013. Concepts of hydrological connectivity: Research approaches, pathways and future agendas. Earth-Sci. Rev. 119, 17-34. https://doi.org/10.1016/j.earscirev.2013.02.001

Brown, A.E., Zhang, L., McMahon, T.A., Western, A.W., Vertessy, R.A., 2005. A review of paired catchment studies for determining changes in water yield resulting from alterations in vegetation. J. Hydrol. 310, 28-61. https://doi.org/10.1016/j.jhydrol.2004.12.010

Brunet, P., Clément, R., Bouvier, C., 2010. Monitoring soil water content and deficit using Electrical Resistivity Tomography (ERT) - A case study in the Cevennes area, France. J. Hydrol. 380, 146-153. https://doi.org/10.1016/j.jhydrol.2009.10.032

Carroll, Z.L., Bird, S.B., Emmett, B.A., Reynolds, B., Sinclair, F.L., 2004. Can tree shelterbelts on agricultural land reduce flood risk? Soil Use Manag. 20, 357-359. https://doi.org/10.1111/j.1475-2743.2004.tb00381.x

Cassiani, G., Godio, A., Stocco, S., Villa, A., Deiana, R., Frattini, P., Rossi, M., 2009. Monitoring the hydrologic behaviour of a mountain slope via time-lapse electrical resistivity tomography. Near Surf. Geophys. 7, 475-486.

Cassiani, G., Ursino, N., Deiana, R., Vignoli, G., Boaga, J., Rossi, M., Perri, M.T., Blaschek, M., Duttmann, R., Meyer, S., Ludwig, R., Soddu, A., Dietrich, P., Werban, U., 2012. Noninvasive Monitoring of Soil Static Characteristics and Dynamic States: A Case Study Highlighting Vegetation Effects on Agricultural Land. Vadose Zone J. 11. https://doi.org/10.2136/vzj2011.0195

Chambers, J.E., Gunn, D.A., Wilkinson, P.B., Meldrum, P.I., Haslam, E., Holyoake, S., Kirkham, M., Kuras, O., Merritt, A., Wragg, J., 2014. 4D electrical resistivity 
tomography monitoring of soil moisture dynamics in an operational railway 0604.2013002

Chandler, K.R., Stevens, C.J., Binley, A., Keith, A.M., 2018. Influence of tree species and forest land use on soil hydraulic conductivity and implications for surface runoff generation. Geoderma 310, 120-127. https://doi.org/10.1016/j.geoderma.2017.08.011

Crow, P., 2005. The Influence of Soils and Species on Tree Root Depth, Information note. Forestry Commission, Edinburgh.

Dadson, S., Hall, J., Murgatroyd, A., Acreman, M., Bates, P., Beven, K., Heathwaite, L., Holden, J., Holman, I., Lane, S., O’Connell, E., Penning-Rowsell, E., Reynard, N., Sear, D., Thorne, C., Wilby, R., 2017. A restatement of the natural science evidence concerning catchment-based 'natural' flood management in the UK. Proc. R. Soc. A. 473, 20160706. https://doi.org/10.1098/rspa.2016.0706

Detty, J.M., McGuire, K.J., 2010a. Topographic controls on shallow groundwater dynamics: implications of hydrologic connectivity between hillslopes and riparian zones in a till mantled catchment. Hydrol. Process. 24, 2222-2236. https://doi.org/10.1002/hyp.7656

277 Detty, J.M., McGuire, K.J., 2010b. Threshold changes in storm runoff generation at a till278 mantled headwater catchment. Water Resour. Res. 46, W07525. https://doi.org/10.1029/2009wr008102

280 Environment Agency, 2018. Working with Natural Processes - Evidence Directory (No. SC150005). Environment Agency, Bristol. 
282 Evaristo, J., McDonnell, J.J., 2019. Global analysis of streamflow response to forest management. Nature. 570, 455-461. https://doi.org/10.1038/s41586-019-1306-0

284 Filoso, S., Bezerra, M.O., Weiss, K.C.B., Palmer, M.A., 2017. Impacts of forest 285 restoration on water yield: A systematic review. PLOS ONE 12, e0183210. https://doi.org/10.1371/journal.pone.0183210

Fraser, A.I., Gardiner, J.B.H., 1967. Rooting and Stability in Sitka Spruce (No. 40), Forestry Commission Bulletin. Forestry Commission, Farnham.

Fu, B.-J., Wang, Y.-F., Lu, Y.-H., He, C.-S., Chen, L.-D., Song, C.-J., 2009. The effects 290 of land-use combinations on soil erosion: a case study in the Loess Plateau of China. Prog. Phys. Geogr. Earth Environ. 33, 793-804. https://doi.org/10.1177/0309133309350264

Garcia-Montiel, D.C., Coe, M.T., Cruz, M.P., Ferreira, J.N., da Silva, E.M., Davidson, 294 E.A., 2008. Estimating Seasonal Changes in Volumetric Soil Water Content at Landscape Scales in a Savanna Ecosystem Using Two-Dimensional Resistivity Profiling. Earth Interact. 12, 1-25. https://doi.org/10.1175/2007El238.1

297 Ghestem, M., Sidle, R.C., Stokes, A., 2011. The Influence of Plant Root Systems on Subsurface Flow: Implications for Slope Stability. BioScience 61, 869-879. https://doi.org/10.1525/bio.2011.61.11.6

300 Graham, M.T., Ball, D.F., Ó Dochartaigh, B.É., MacDonald, A.M., 2009. Using 301 302 303 transmissivity, specific capacity and borehole yield data to assess the productivity of Scottish aquifers. Q. J. Eng. Geol. Hydrogeol. 42, 227-235. https://doi.org/10.1144/1470-9236/08-045

304 Granger, R.J., Gray, D.M., 1989. Evaporation from natural nonsaturated surfaces. J. 305 Hydrol. 111, 21-29. https://doi.org/10.1016/0022-1694(89)90249-7 
306 Greenwood, W.J., Buttle, J.M., 2014. Effects of reforestation on near-surface saturated hydraulic conductivity in a managed forest landscape, southern Ontario, Canada. Ecohydrology 7, 45-55. https://doi.org/10.1002/eco.1320

309

310

311

312

313

314

315

316

317

318

319

320

321

322

323

324

325

326

327

328

329

Guswa, A.J., 2012. Canopy vs. Roots: Production and Destruction of Variability in Soil Moisture and Hydrologic Fluxes. Vadose Zone J. 11, 1-13. https://doi.org/doi:10.2136/vzj2011.0159

Haddad, N.M., Brudvig, L.A., Clobert, J., Davies, K.F., Gonzalez, A., Holt, R.D., Lovejoy, T.E., Sexton, J.O., Austin, M.P., Collins, C.D., Cook, W.M., Damschen, E.I., Ewers, R.M., Foster, B.L., Jenkins, C.N., King, A.J., Laurance, W.F., Levey, D.J., Margules, C.R., Melbourne, B.A., Nicholls, A.O., Orrock, J.L., Song, D.-X., Townshend, J.R., 2015. Habitat fragmentation and its lasting impact on Earth's ecosystems. Sci. Adv. 1, e1500052. https://doi.org/10.1126/sciadv.1500052

Hewlett, J.D., Hibbert, A.R., 1967. Factors affecting the response of small watersheds to precipitation in humid areas, in: Sopper, W.E., Lull, H.W. (Eds.), Forest Hydrology. Pergamon Press, New York, pp. 275-90.

Hornbeck, J.W., Pierce, R.S., Federer, C.A., 1970. Streamflow changes after forest clearing in New England. Water Resour. Res. 6, 1124-1132.

Ilstedt, U., Bargués Tobella, A., Bazié, H.R., Bayala, J., Verbeeten, E., Nyberg, G., Sanou, J., Benegas, L., Murdiyarso, D., Laudon, H., Sheil, D., Malmer, A., 2016. Intermediate tree cover can maximize groundwater recharge in the seasonally dry tropics. Sci. Rep. 6, 21930. https://doi.org/10.1038/srep21930

Jackson, B.M., Wheater, H.S., McIntyre, N.R., Chell, J., Francis, O.J., Frogbrook, Z., Marshall, M., Reynolds, B., Solloway, I., 2008. The impact of upland land management on flooding: insights from a multiscale experimental and modelling 

318X.2008.00009.x

332

333

Jayawickreme, D.H., Van Dam, R.L., Hyndman, D.W., 2008. Subsurface imaging of vegetation, climate, and root-zone moisture interactions. Geophys. Res. Lett. 35. https://doi.org/10.1029/2008GL034690

Jipp, P.H., Nepstad, D.C., Cassel, D.K., de Carvalho, C.R., 1998. Deep Soil Moisture Storage and Transpiration in Forests and Pastures of Seasonally-Dry Amazonia, in: Markham, A. (Ed.), Potential Impacts of Climate Change on Tropical Forest Ecosystems. Springer Netherlands, Dordrecht, pp. 255-272. https://doi.org/10.1007/978-94-017-2730-3_11

Johnson, R.C., 1995. Effects of upland afforestation on water resources - The Balquhidder Experiment 1981-1991, IH Report No. 116 (2 ${ }^{\text {nd }}$ edition). Institute of Hydrology, Crowmarsh Gifford.

Klaus, J., Jackson, C.R., 2018. Interflow Is Not Binary: A Continuous Shallow Perched Layer Does Not Imply Continuous Connectivity. Water Resour. Res. 54, 59215932. https://doi.org/10.1029/2018WR022920

Kohler, M.A., Linsley, R.K., 1951. Predicting the runoff from storm rainfall. US Department of Commerce, Weather Bureau, Washington DC.

Lane, S.N., 2017. Natural flood management. Wiley Interdiscip. Rev. Water 4, e1211. https://doi.org/10.1002/wat2.1211

Liu, J., Gao, G., Wang, S., Jiao, L., Wu, X., Fu, B., 2018. The effects of vegetation on runoff and soil loss: Multidimensional structure analysis and scale characteristics. J. Geogr. Sci. 28, 59-78. https://doi.org/10.1007/s11442-018-1459-z 
353 Loke, M.H., Chambers, J.E., Rucker, D.F., Kuras, O., Wilkinson, P.B., 2013. Recent developments in the direct-current geoelectrical imaging method. J. Appl. Geophys. 95, 135-156. https://doi.org/10.1016/j.jappgeo.2013.02.017

356

357

358

359

360

361

362

363

364

365

366

367

368

369

370

371

372

373

374

375

Lunka, P., Patil, S.D., 2016. Impact of tree planting configuration and grazing restriction on canopy interception and soil hydrological properties: implications for flood mitigation in silvopastoral systems. Hydrol. Process. 30, 945-958. https://doi.org/10.1002/hyp.10630

MacDonald, A.M., Maurice, L., Dobbs, M.R., Reeves, H.J., Auton, C.A., 2012. Relating in situ hydraulic conductivity, particle size and relative density of superficial deposits in a heterogeneous catchment. J. Hydrol. 434-435, 130-141. https://doi.org/10.1016/j.jhydrol.2012.01.018

Marshall, M.R., Francis, O.J., Frogbrook, Z.L., Jackson, B.M., Mclntyre, N., Reynolds, B., Solloway, I., Wheater, H.S., Chell, J., 2009. The impact of upland land management on flooding: results from an improved pasture hillslope. Hydrol. Process. 23, 464-475.

Masson, J., 2019. How do barometric seiche waves affect historic and current flood magnitude and seasonality at Portmore and Talla reservoirs? (Unpublished BSc dissertation). School of Social Sciences, University of Dundee, Dundee.

McNamara, J.P., Chandler, D., Seyfried, M., Achet, S., 2005. Soil moisture states, lateral flow, and streamflow generation in a semi-arid, snowmelt-driven catchment. Hydrol. Process. 19, 4023-4038.

Nisbet, T.R., 2005. Water use by trees, Information Note No. FCIN065. Forestry Commission, Edinburgh. 
376 Ó Dochartaigh, B.É., Archer, N.A.L., Peskett, L., MacDonald, A.M., Black, A.R., Auton, 377 C.A., Merritt, J.E., Gooddy, D.C., Bonell, M., 2018. Geological structure as a 378 control on floodplain groundwater dynamics. Hydrogeol. J. 27, 703-716. https://doi.org/10.1007/s10040-018-1885-0

380 Ó Dochartaigh, B.É., MacDonald, A.M., Fitzsimons, V., Ward, R., 2015. Scotland's aquifers and groundwater bodies (Open Report No. OR/15/028). British Geological Survey, Keyworth.

Reaney, S.M., Bracken, L.J., Kirkby, M.J., 2014. The importance of surface controls on overland flow connectivity in semi-arid environments: results from a numerical experimental approach. Hydrol. Process. 28, 2116-2128. https://doi.org/10.1002/hyp.9769

387 Scherrer, S., Naef, F., Faeh, A.O., Cordery, I., 2007. Formation of runoff at the hillslope scale during intense precipitation. Hydrol Earth Syst Sci, 11, 907-922.

Soulsby, C., Dick, J., Scheliga, B., Tetzlaff, D., 2017. Taming the flood-How far can we go with trees? Hydrol. Process. 31, 3122-3126. https://doi.org/10.1002/hyp.11226

Swank, W.T., Swift Jr, L.W., Douglass, J.E., 1988. Streamflow changes associated with forest cutting, species conversions, and natural disturbances, in: Swank, W.T., Crossley Jr, D.A. (Eds.), Forest Hydrology and Ecology at Coweeta. SpringerVerlag, New York, pp. 297-312.

Tromp-van Meerveld, H.J., McDonnell, J.J., 2006. Threshold relations in subsurface stormflow: 2. The fill and spill hypothesis. Water Resour. Res. 42, W02411. 0.1029/2004WR003800 
399 Tweed Forum, 2019. The Eddleston Water Project [WWW Document]. https://tweedforum.org/our-work/projects/the-eddleston-water-project/

401 Uchida, T., McDonnell, J.J., Asano, Y., 2006. Functional intercomparison of hillslopes 402 and small catchments by examining water source, flowpath and mean residence 403 time. J. Hydrol. 327, 627-642. https://doi.org/10.1016/j.jhydrol.2006.02.037

Uchida, T., Tromp-van Meerveld, I., McDonnell, J.J., 2005. The role of lateral pipe flow in 405 406 hillslope runoff response: an intercomparison of non-linear hillslope response. J. Hydrol. 311, 117-133. https://doi.org/10.1016/j.jhydrol.2005.01.012

407 Wenninger, J., Uhlenbrook, S., Tilch, N., Leibundgut, C., 2004. Experimental evidence of 408 409 fast groundwater responses in a hillslope/floodplain area in the Black Forest Mountains, Germany. Hydrol. Process. 18, 3305-3322. https://doi.org/10.1002/hyp.5686

Werritty, A., Ball, T., Spray, C., Bonell, M., Rouillard, J., Archer, N.A.L., 2010. Restoration strategy: Eddleston Water Scoping Study. University of Dundee, Dundee.

Wheater, H., Evans, E., 2009. Land use, water management and future flood risk. Land Use Policy 26, S251-S264.

416 Wheater, H., Reynolds, B., McIntyre, N., Marshall, M., Jackson, B., Frogbrook, Z., 417 Solloway, I., Francis, O., Chell, J., 2008. Impacts of upland land management on 418 flood risk: Multi-scale modelling methodology and results from the Pontbren 419 experiment (No. UR 16), FRMRC Research Report. University of Manchester, $420 \quad$ Manchester. https://nora.nerc.ac.uk/id/eprint/5890/1/ur16_impacts_upland_land_management 422 _wp2_2_v1_0.pdf 
423 Ziegler, A.D., Giambelluca, T.W., Tran, L.T., Vana, T.T., Nullet, M.A., Fox, J., Vien, T.D., 424 Pinthong, J., Maxwell, J.F., Evett, S., 2004. Hydrological consequences of 425 landscape fragmentation in mountainous northern Vietnam: evidence of 426 accelerated overland flow generation. J. Hydrol. 287, 124-146. https://doi.org/10.1016/j.jhydrol.2003.09.027

428 Zimmermann, B., Elsenbeer, H., De Moraes, J.M., 2006. The influence of land-use 429 changes on soil hydraulic properties: Implications for runoff generation. For. Ecol. 430 Manag. 222, 29-38. https://doi.org/10.1016/j.foreco.2005.10.070 


\section{Supplementary Information on:}

\section{The impact of across-slope forest strips on hillslope subsurface hydrological dynamics}

Leo Pesketta,b*

Alan MacDonald

Kate Heal ${ }^{\mathrm{a}}$

Jeffrey J. McDonnell ${ }^{c, d}$

Jon Chambers ${ }^{\mathrm{e}}$

Sebastian Uhlemann ${ }^{\mathrm{e}, 2}$

Kirsty Upton ${ }^{b}$

Andrew Black ${ }^{\dagger}$

aUniversity of Edinburgh, School of GeoSciences, Crew Building, Alexander Crum Brown Road, Edinburgh EH9 3FF, United Kingdom leo.peskett@ed.ac.uk

\footnotetext{
2 Present address: Earth \& Environmental Sciences, Lawrence Berkeley National Laboratory, Berkeley, CA 94720, USA
} 


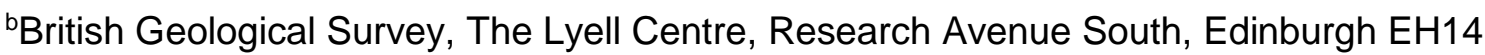
4AP, United Kingdom

'Global Institute for Water Security, School of Environment and Sustainability, University of Saskatchewan, Saskatoon SK S7N 3H5, Canada

dSchool of Geography, Earth and Environmental Sciences, University of Birmingham, Birmingham B15 2TT, United Kingdom

eBritish Geological Survey, Environmental Science Centre, Nicker Hill, Keyworth, Nottingham NG12 5GG, United Kingdom

'Geography and Environmental Science, Tower Building, University of Dundee, Dundee DD1 4HN, United Kingdom

*Corresponding author: Leo Peskett, leo.peskett@ed.ac.uk

\section{Contents of this file}

Number of pages: 9

Number of figures: 5

Number of tables: $\quad 4$ 
Figure S1: a) Borehole logs for each of the piezometer sites; b) section of grassland soil pit G2 at ( 0.6 m depth at base of photo); c) view into soil pit at F2b in the forest strip.

a)

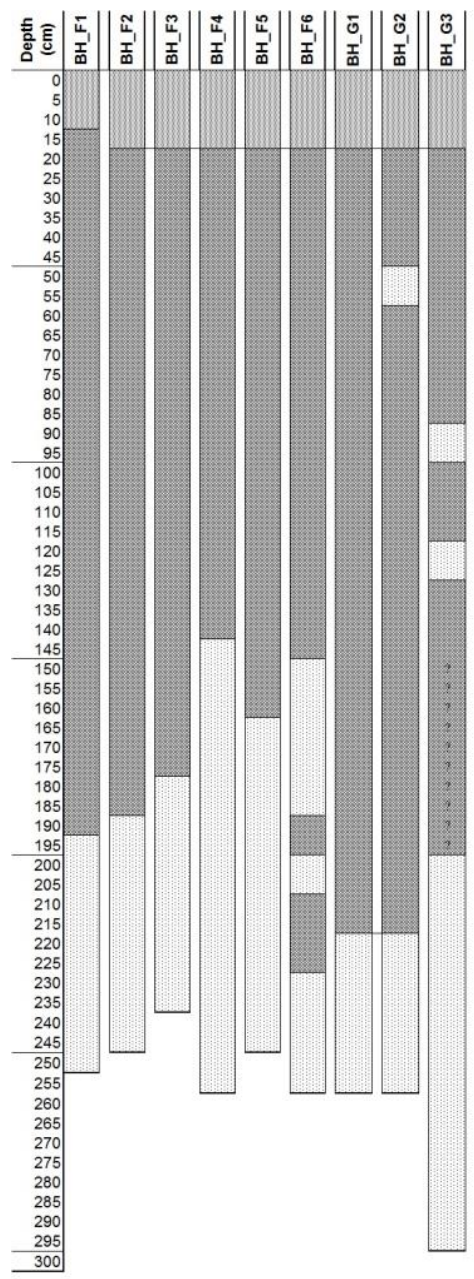

b)

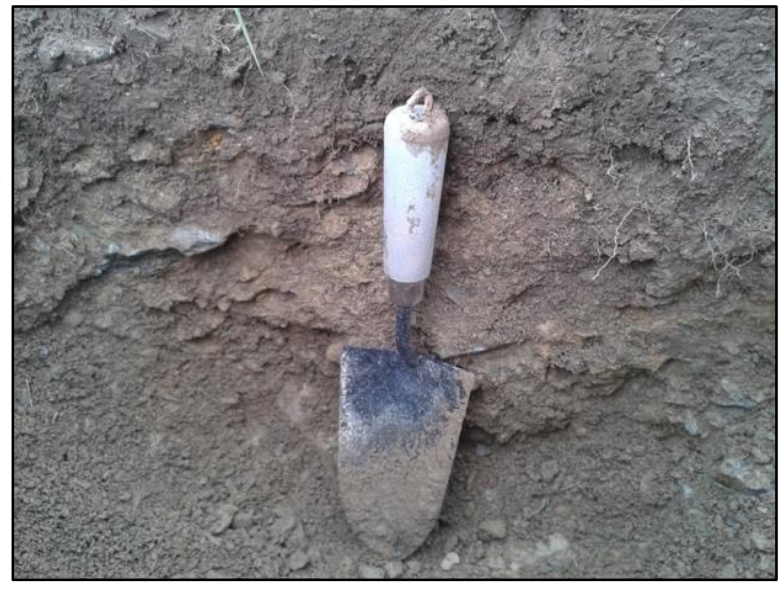

c)

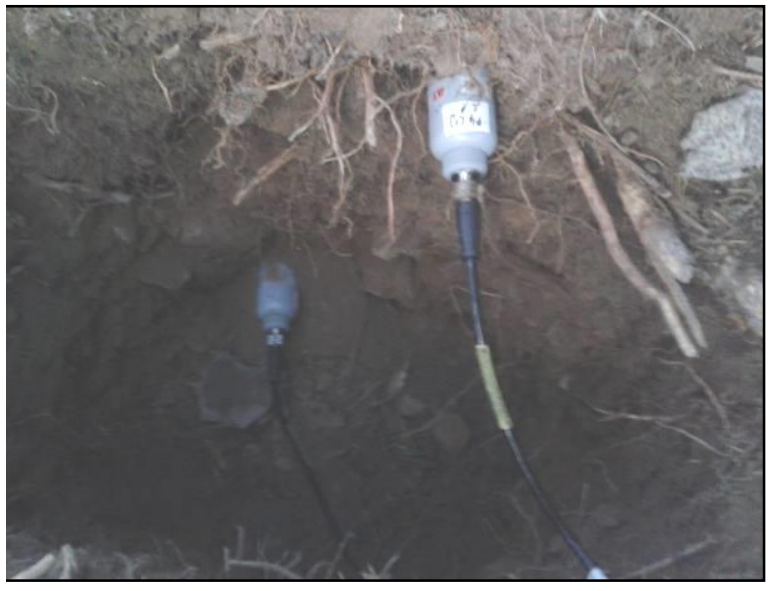


Figure S2: Resistivity measurements in four surveys in different seasons relative to June 2017 survey. Black lines mark outside edges of forest strip.

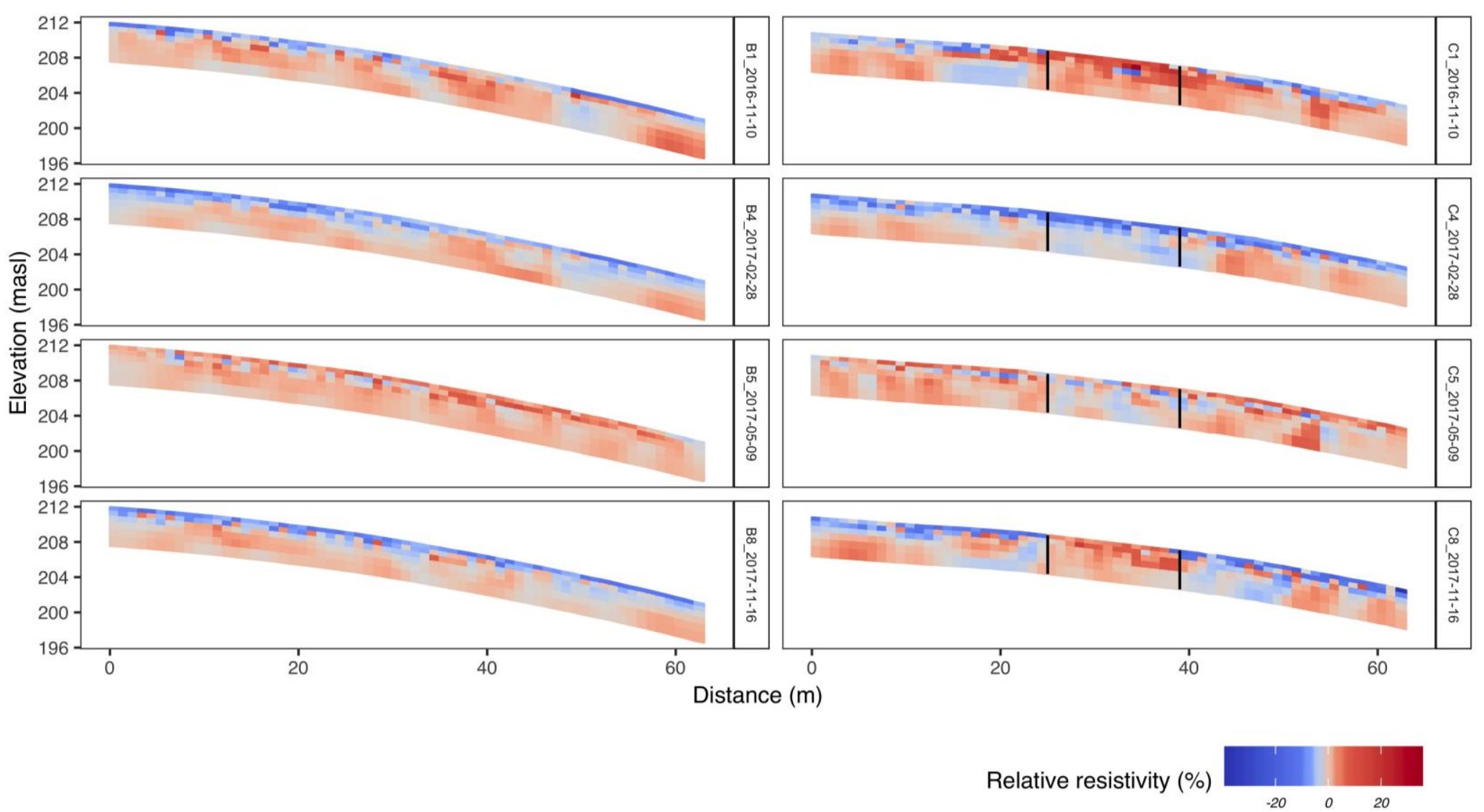


Figure S3: Pairwise comparison of soil moisture and groundwater TTR between the two transects and between seasons for all rainfall events analysed $(n=52)$. Pairs are filtered to contain only events when sensors on each transect responded and the event sample size for each pair is denoted in italics. The horizontal line inside the box represents the median and the lower and upper hinges correspond to the first and third quartiles. The upper and lower whiskers depict the largest and smallest values respectively within 1.5 * the interquartile range (IQR). Numbers in italics show the number of events in which sensor responded. Dots are outliers.

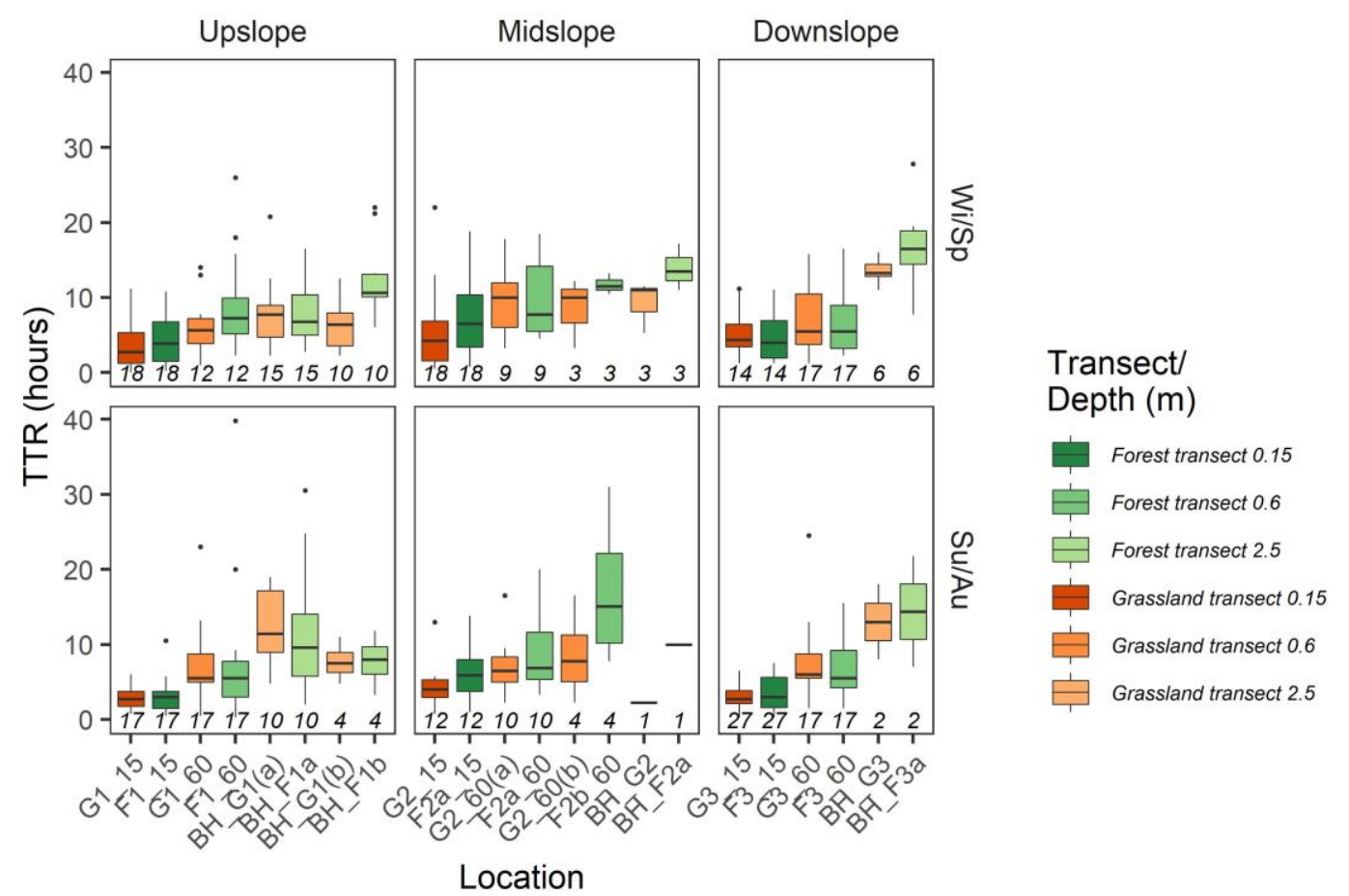


Figure S4: a) Time to peak from the start of rainfall (TTPR) for the different domains and depths on the forest strip and grassland transects during nine rainfall events when the borehole downslope of the forest responded and the majority of the other soil moisture and groundwater sensors responded. b) Pairwise comparison of soil moisture and groundwater TTPR between the two transects and between seasons for all events $(n=52)$. Pairs are filtered to contain only events when sensors on each transect are active and the event sample size for each pair is denoted in italics. The horizontal line inside the box represents the median and the lower and upper hinges correspond to the first and third quartiles. The upper and lower whiskers depict the largest and smallest values respectively within 1.5 * the interquartile range (IQR). Numbers in italics show the number of events in which sensor responded. Dots are outliers.

a)

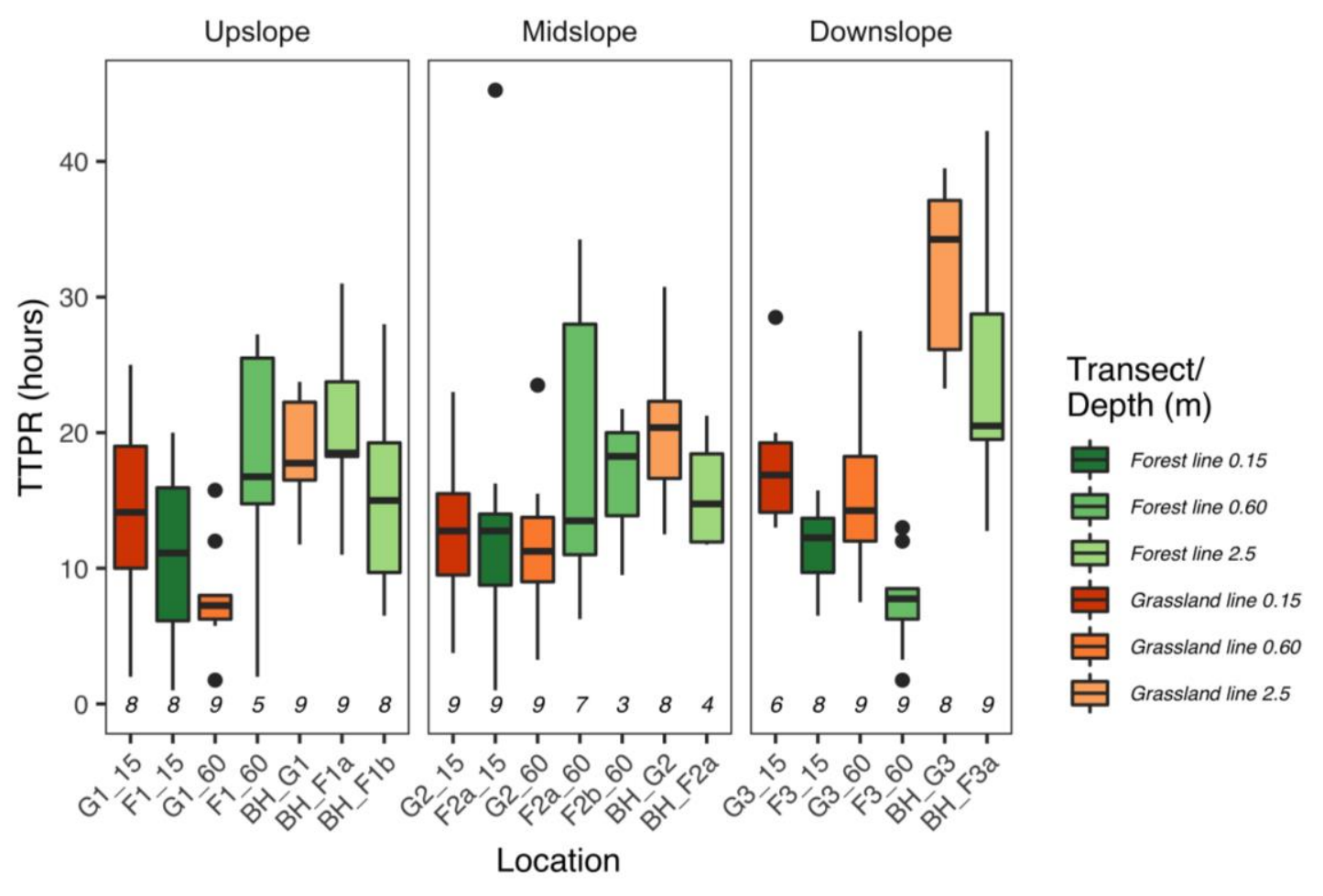


b

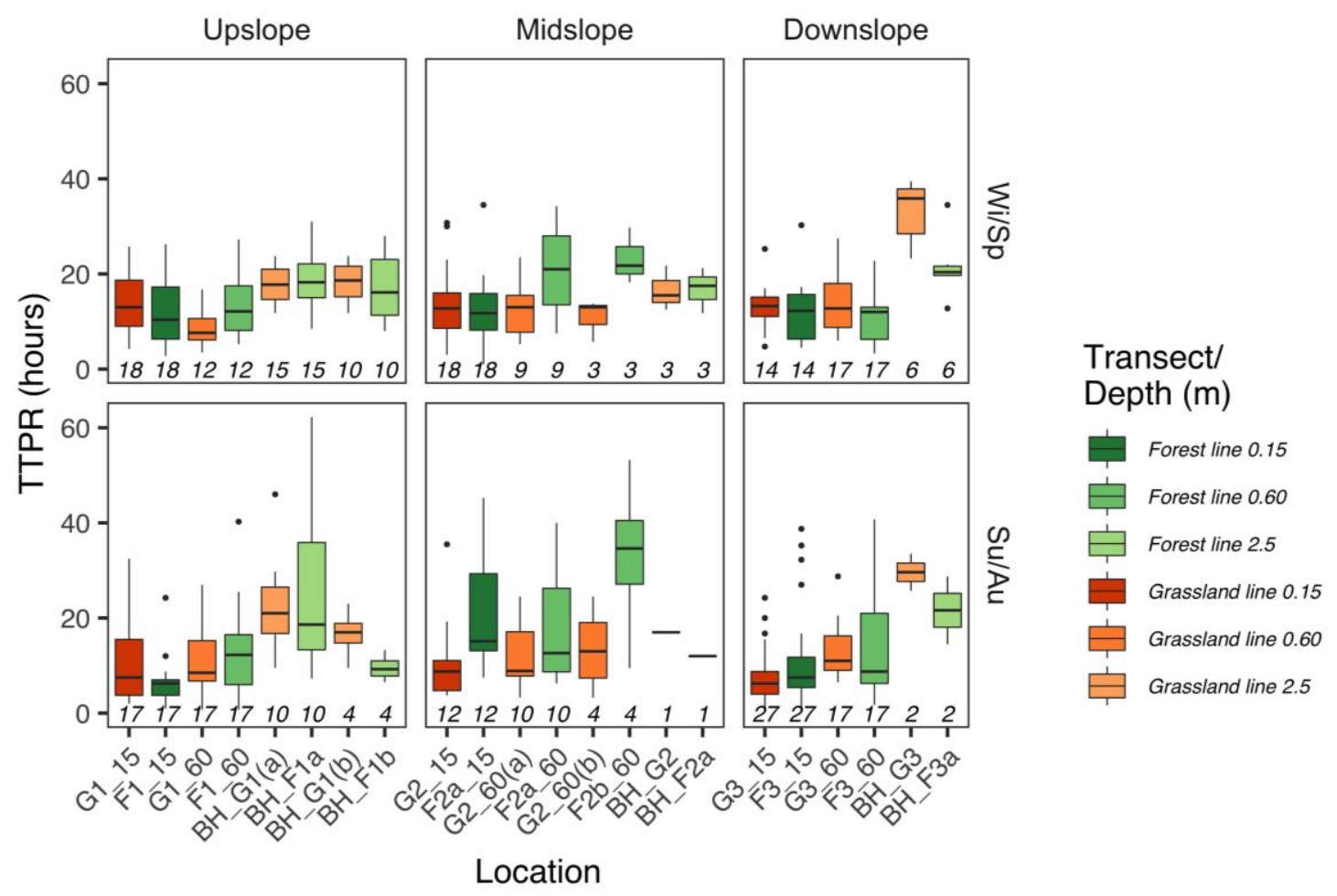


Table S1: Soil properties at each soil moisture sensor location

\begin{tabular}{|c|c|c|c|c|c|c|c|}
\hline Location & $\begin{array}{c}\text { Depth } \\
\text { (m) }\end{array}$ & $\begin{array}{r}\text { Clay } \\
\text { (\%f }\end{array}$ & ion $b$ & Sand & $\begin{array}{l}\text { Gravel and } \\
\text { cobbles } \\
\text { (\% of total } \\
\text { by mass) }\end{array}$ & $\begin{array}{l}\text { Organic } \\
\text { content } \\
\text { (\% of total by } \\
\text { mass) }\end{array}$ & Soil texture \\
\hline G1_15 & 0.15 & 9.83 & 65.4 & 24.8 & 37.0 & 6.95 & Silty loam \\
\hline F1_15 & 0.15 & 18.0 & 65.0 & 17.0 & 22.3 & 5.67 & Silty loam \\
\hline G1_60 & 0.60 & 12.1 & 48.6 & 39.3 & 55.5 & 2.03 & Loam \\
\hline F1_60 & 0.60 & 14.1 & 63.4 & 22.6 & 25.3 & 4.44 & Silty loam \\
\hline G2_15 & 0.15 & 15.3 & 63.6 & 21.1 & 53.4 & 4.91 & Silty loam \\
\hline F2a_15 & 0.15 & 10.7 & 53.7 & 35.6 & 49.0 & 1.97 & Silty loam \\
\hline F2b_15 & 0.15 & 11.2 & 64.8 & 24.0 & 26.1 & 5.73 & Silty loam \\
\hline G2_60 & 0.60 & 11.3 & 65.8 & 23.0 & 44.5 & 2.63 & Silty loam \\
\hline F2a_60 & 0.60 & 11.3 & 64.1 & 24.6 & 32.9 & 6.07 & Silty loam \\
\hline F2b_60 & 0.60 & 16.8 & 62.8 & 20.5 & 58.2 & 2.78 & Silty loam \\
\hline G3_15 & 0.15 & 11.5 & 60.0 & 28.6 & 44.6 & 5.19 & Silty loam \\
\hline F3_15 & 0.15 & 10.6 & 68.8 & 20.6 & 30.0 & 5.32 & Silty loam \\
\hline G3_60 & 0.60 & 13.5 & 67.7 & 18.8 & 40.7 & 4.20 & Silty loam \\
\hline F3_60 & 0.60 & 10.6 & 63.5 & 25.9 & 39.2 & 3.03 & Silty loam \\
\hline
\end{tabular}


Table S2: Summary of rainfall events selected $(n=52)$ and key event characteristics used in the analysis. Percentage of sensors responding is based on all working soil moisture and groundwater sensors at the site $(n=20)$.

\begin{tabular}{|c|c|c|c|c|c|}
\hline Rainfall start time & $\begin{array}{l}\text { No. } \\
\text { responding } \\
(\%)\end{array}$ & $\begin{array}{l}\text { Total } \\
\text { rainfall, TR } \\
(\mathrm{mm})\end{array}$ & $\begin{array}{l}\text { Intensity, I } \\
\left(m m h^{-1}\right)\end{array}$ & $A W I(m m)$ & AP28d $(\mathrm{mm})$ \\
\hline $11 / 11 / 1620: 15$ & 50 & 19.8 & 2.4 & 4.8 & 13.2 \\
\hline $16 / 11 / 1611: 00$ & 68 & 19.0 & 1.1 & 26.8 & 45.2 \\
\hline 21/11/16 19:30 & 91 & 41.0 & 2.5 & 11.6 & 67.0 \\
\hline $22 / 12 / 16$ 15:00 & 64 & 8.6 & 2.0 & 3.8 & 14.2 \\
\hline 23/12/16 08:45 & 77 & 20.2 & 1.7 & 11.6 & 23.2 \\
\hline $24 / 12 / 1600: 15$ & 77 & 17.4 & 1.3 & 30.5 & 43.0 \\
\hline 03/02/17 18:30 & 50 & 8.2 & 0.8 & 4.3 & 34.6 \\
\hline 23/02/17 00:15 & 82 & 21.8 & 1.3 & 11.0 & 49.4 \\
\hline 24/02/17 17:45 & 77 & 15.2 & 0.8 & 28.4 & 71.4 \\
\hline 17/03/17 02:00 & 68 & 13.2 & 0.7 & 2.0 & 87.6 \\
\hline 18/03/17 20:00 & 59 & 10.2 & 0.7 & 16.7 & 102 \\
\hline 21/03/17 09:30 & 64 & 9.8 & 1.7 & 28.8 & 114 \\
\hline 22/03/17 21:15 & 73 & 11.2 & 1.0 & 29.8 & 122 \\
\hline 20/05/17 00:15 & 32 & 11.0 & 0.8 & 6.8 & 15.6 \\
\hline 05/06/17 19:30 & 64 & 48.0 & 1.5 & 6.7 & 40.0 \\
\hline 08/06/17 07:30 & 64 & 14.8 & 2.0 & 48.3 & 87.8 \\
\hline 15/06/17 12:15 & 27 & 9.0 & 1.5 & 3.5 & 100 \\
\hline 27/06/17 00:15 & 24 & 11.2 & 1.0 & 2.0 & 89.8 \\
\hline 28/06/17 23:15 & 76 & 52.6 & 1.5 & 10.7 & 100 \\
\hline 04/07/17 03:45 & 43 & 10.8 & 0.8 & 38.7 & 138 \\
\hline 26/07/17 06:00 & 24 & 11.6 & 1.6 & 8.5 & 96.8 \\
\hline 14/08/17 03:15 & 24 & 9.8 & 1.4 & 4.9 & 63.4 \\
\hline $14 / 08 / 1720: 45$ & 67 & 20.8 & 2.2 & 14.0 & 72.8 \\
\hline 23/08/17 05:00 & 24 & 8.2 & 2.2 & 4.6 & 97.0 \\
\hline 21/09/17 03:00 & 38 & 10.2 & 1.9 & 5.7 & 70.4 \\
\hline 24/09/17 22:15 & 62 & 20.8 & 2.0 & 9.9 & 77.6 \\
\hline 04/10/17 14:45 & 62 & 14.6 & 1.3 & 12.3 & 97.6 \\
\hline
\end{tabular}




\begin{tabular}{|c|c|c|c|c|c|}
\hline 11/10/17 00:45 & 58 & 11.4 & 0.9 & 5.0 & 89.8 \\
\hline 19/11/17 19:30 & 59 & 18.8 & 0.5 & 6.5 & 32.8 \\
\hline 22/11/17 02:45 & 82 & 25.2 & 1.0 & 20.2 & 50.0 \\
\hline 24/12/17 23:00 & 68 & 20.0 & 0.9 & 4.8 & 21.8 \\
\hline 30/12/17 02:45 & 55 & 19.6 & 0.7 & 12.0 & 41.6 \\
\hline 02/01/18 20:45 & 68 & 15.2 & 1.0 & 21.4 & 65.4 \\
\hline 22/01/18 05:45 & 73 & 17.2 & 1.3 & 4.4 & 83.6 \\
\hline 10/02/18 18:00 & 68 & 8.6 & 0.9 & 4.8 & 78.4 \\
\hline 18/02/18 16:30 & 41 & 8.2 & 0.6 & 3.1 & 86.8 \\
\hline 05/03/18 20:15 & 82 & 13.0 & 1.0 & 6.0 & 42.8 \\
\hline 10/03/18 05:00 & 77 & 10.2 & 0.7 & 16.1 & 55.6 \\
\hline 12/05/18 23:30 & 23 & 8.8 & 1.1 & 8.7 & 40.2 \\
\hline 01/06/18 12:00 & 32 & 18.2 & 2.5 & 1.4 & 19.2 \\
\hline 19/06/18 18:00 & 59 & 37.2 & 2.5 & 5.5 & 38.4 \\
\hline 27/07/18 21:30 & 23 & 12.0 & 1.5 & 9.3 & 20.6 \\
\hline 01/08/18 14:30 & 18 & 10.8 & 1.4 & 25.1 & 50.4 \\
\hline 11/08/18 23:15 & 14 & 11.4 & 1.0 & 8.1 & 70.2 \\
\hline 18/08/18 22:15 & 32 & 12.2 & 1.2 & 11.4 & 90.4 \\
\hline 03/09/18 04:00 & 27 & 11.4 & 1.2 & 1.3 & 66.2 \\
\hline 10/09/18 14:00 & 41 & 12.4 & 1.1 & 5.0 & 61.0 \\
\hline 19/09/18 07:00 & 46 & 17.4 & 1.8 & 11.3 & 60.6 \\
\hline 12/10/18 12:15 & 32 & 9.6 & 2.1 & 10.0 & 51.2 \\
\hline 13/10/18 04:45 & 55 & 17.6 & 1.3 & 17.9 & 57.6 \\
\hline 31/10/18 22:30 & 46 & 9.4 & 1.4 & 4.1 & 49.8 \\
\hline 09/11/18 17:30 & 59 & 12.2 & 1.0 & 5.7 & 44.6 \\
\hline
\end{tabular}


Table S3: Spearman rank correlation coefficients calculated to compare relationships between different rainfall event characteristics. ${ }^{\star} p<0.05$; ${ }^{\star} p<$ $0.01 ;{ }^{* * *} p<0.001$.

\begin{tabular}{l|lll}
\hline & Rainfall $(\mathrm{mm})$ & Intensity $\left(\mathrm{mm} \mathrm{h}^{-1}\right)$ & AWI $(\mathrm{mm})$ \\
\hline Intensity $\left(\mathrm{mm} \mathrm{h}^{-1}\right)$ & $0.32^{*}$ & 1.00 & \\
AWI $(\mathrm{mm})$ & 0.00 & -0.05 & 1.00 \\
AP28d $(\mathrm{mm})$ & -0.14 & -0.08 & $0.33^{*}$ \\
\hline
\end{tabular}


Table S4: Spearman rank correlation coefficients between rainfall event characteristics / antecedent conditions and response metrics for all soil moisture sensors and for all piezometers across both the forest strip and grassland transects. Coefficients are shown for all events $(n=52)$ and separately for events in Winter/Spring (Wi/Sp, $n=20)$ and Summer/Autumn $(\mathrm{Su} / \mathrm{Au}, \mathrm{n}=32) .{ }^{*} p<0.05 ;{ }^{* *} p<0.01$; ${ }^{\star * *} p<0.001$.

\begin{tabular}{|c|c|c|c|c|c|c|c|c|c|}
\hline \multirow[b]{2}{*}{$\begin{array}{l}\text { Soil moisture } \\
\text { sensors }\end{array}$} & \multicolumn{3}{|c|}{$\begin{array}{l}\text { Time to response from the start of rainfall } \\
(T T R, h)\end{array}$} & \multicolumn{3}{|c|}{$\begin{array}{l}\text { Time to peak from start of rainfall (TTPR, } \\
\text { h) }\end{array}$} & \multicolumn{3}{|c|}{$\begin{array}{l}\text { Maximum absolute rise (MR, } \mathrm{m}^{3} \mathrm{~m}^{-3} \text { for soil } \\
\text { moisture and } m \text { for groundwater level) }\end{array}$} \\
\hline & All & Wi/Sp & $S u / A u$ & All & Wi/Sp & $\mathrm{Su} / \mathrm{Au}$ & All & Wi/Sp & $S u / A u$ \\
\hline Total rainfall (mm) & 0.0286 & -0.0043 & $0.136^{*}$ & $0.151^{* * *}$ & $0.232^{* * *}$ & $0.194^{\star *}$ & $0.295^{\star * *}$ & $0.263^{\star \star *}$ & $0.271^{* * *}$ \\
\hline Intensity $\left(\mathrm{mm} \mathrm{h}^{-1}\right)$ & $-0.375^{\star \star *}$ & $-0.402^{\star \star \star}$ & $-0.375^{\star \star *}$ & $-0.437^{\star * \star}$ & $-0.458^{\star * \star}$ & $-0.365^{\star \star *}$ & $0.225^{\star \star *}$ & 0.123 & $0.175^{\star \star}$ \\
\hline AWI (mm) & 0.0596 & 0.0152 & 0.0401 & 0.0121 & -0.112 & 0.0771 & 0.0142 & 0.0768 & -0.0376 \\
\hline AP28d (mm) & 0.0306 & 0.081 & 0.0228 & -0.000769 & 0.0627 & 0.0115 & $-0.132^{\star *}$ & $-0.225^{\star \star}$ & -0.0614 \\
\hline Piezometers & All & Wi/Sp & $\mathrm{Su} / \mathrm{Au}$ & All & Wi/Sp & $\mathrm{Su} / \mathrm{Au}$ & All & Wi/Sp & $\mathrm{Su} / \mathrm{Au}$ \\
\hline Total rainfall $(\mathrm{mm})$ & 0.0844 & 0.146 & -0.0714 & 0.121 & 0.152 & 0.0501 & $0.325^{\star \star \star}$ & $0.287^{\star}$ & $0.336^{*}$ \\
\hline Intensity $\left(\mathrm{mm} \mathrm{h}^{-1}\right)$ & $-0.262^{* *}$ & $-0.337^{\star *}$ & $-0.396^{* *}$ & $-0.309^{* * *}$ & $-0.294^{*}$ & $-0.434^{* *}$ & $0.181^{*}$ & $0.241^{*}$ & 0.0416 \\
\hline AWI (mm) & 0.0118 & -0.0138 & 0.0465 & $-0.232^{*}$ & $-0.39^{\star * *}$ & -0.0314 & -0.113 & -0.169 & 0.0764 \\
\hline AP28d (mm) & 0.00493 & -0.0214 & 0.0614 & -0.0755 & -0.0677 & -0.0686 & 0.00722 & -0.141 & 0.250 \\
\hline
\end{tabular}

